\title{
The Lancet Countdown: Tracking Progress on Health and Climate Change
}

Nick Watts, W. Neil Adger, Sonja Ayeb-Karlsson, Yuqi Bai, Peter Byass, Diarmid Campbell-Lendrum, Tim Colbourn, Peter Cox, Michael Davies, Michael Depledge, Anneliese Depoux, Paula DominguezSalas, Paul Drummond, Paul Ekins, Antoine Flahault, Delia Grace, Hilary Graham, Andy Haines, Ian Hamilton, Anne Johnson, Ilan Kelman, Sari Kovats, Lu Liang, Melissa Lott, Robert Lowe, Yong Luo, Georgina Mace, Mark Maslin, Karyn Morrissey, Kris Murray, Tara Neville, Maria Nilsson, Tadj Oreszczyn, Christine Parthemore, David Pencheon, Elizabeth Robinson, Stefanie Schütte, Joy Shumake-Guillemot, Paolo Vineis, Paul Wilkinson, Nicola Wheeler, Bing Xu, Jun Yang, Yongyuan Yin, Chaoqing Yu, Peng Gong, Hugh Montgomery, Anthony Costello

\section{Abstract}

The Lancet Countdown: Tracking Progress on Health and Climate Change is an international, multidisciplinary research collaboration between academic institutions and practitioners across the world. It follows on from the work of the 2015 Lancet Commission, which concluded that the response to climate change could be "the greatest global health opportunity of the 21st century".

The Lancet Countdown aims to track the health effects of climate change; health resilience and adaptation; health co-benefits of mitigation; climate economics and finance; and political and broader engagement. These focus areas form the five thematic working groups of the Lancet Countdown and represent different aspects of the complex relationships between health and climate change. These thematic groups will provide indicators for a global overview of health and climate change; national case studies highlighting countries leading the way or going against the trend; and engagement with a range of stakeholders.

The Lancet Countdown ultimately aims to report annually on a series of indicators across these five working groups. This paper outlines these potential indicators and indicator domains to be tracked by the collaboration, with suggestions on the methodologies, and data sets available to achieve this end. The proposed indicator domains require further refinement, and mark the beginning of an ongoing consultation process - from November 2016 to early 2017 - to develop these domains, identify key areas not currently covered, and change indicators where necessary. It will actively seek to engage with existing monitoring processes, such as the UN Sustainable Development Goals, and the World Health Organization's Climate and Health Country Profiles. Additionally, the indicators will evolve throughout their lifetime through ongoing collaboration with experts and a range of stakeholders, and dependent on the emergence of new evidence and knowledge. During the course of its work, the Lancet Countdown will adopt a collaborative and iterative process, which aims to complement existing initiatives, welcome engagement with new partners, and be open to developing new research projects on health and climate change. 


\section{Introduction}

The World Health Organization (WHO) estimated that in 2012, 12.6 million deaths (23\% of all deaths) were attributable to modifiable environmental factors, many of which could be influenced by climate change, or are related to the driving forces of climate change. ${ }^{1}$ The $2009 \mathrm{UCL}$-Lancet Commission: Managing the health effects of climate change described the ways in which climate change acts as a force multiplier for threats to global health. ${ }^{2}$ These initiatives have drawn on longstanding expertise and leadership in the health and climate space from institutions such as the WHO and the Intergovernmental Panel on Climate Change's (IPCC). ${ }^{3,4}$

The 2015 Lancet Commission on Health and Climate Change: policy responses to protect public health built on these foundations and explored the health benefits of climate change mitigation and adaptation policies. ${ }^{5}$ As first described in the 2009 Lancet series, greenhouse gas (GHG) mitigation across a range of sectors can result in significant improvements in public health. ${ }^{6-10}$ Taken together, the potential to avoid significant impacts of climate change and the potential co-benefits of climate mitigation and adaptation led the 2015 Lancet Commission to conclude that "tackling climate change could be the greatest global health opportunity of the $21^{\text {st }}$ century". ${ }^{5}$

Direct impacts of climate change result from rising temperatures, heatwaves, and increases in the frequency of complex extreme weather events such as windstorms, floods and droughts. ${ }^{11}$ The health and social consequences of these events are far-reaching, ranging from reduced labour productivity and heat-related deaths, through to direct injury, the spread of infectious disease, and mental health impacts following wide-spread flooding. The effects of climate change will also be heterogeneously mediated across different environmental and social systems, resulting in changing patterns of the burden and distribution of infectious diseases, changes in food productivity and potential effects on food and water shortages, population displacement, and conflict. ${ }^{3}$ Climate change places undue burden on countries least responsible and least able to respond, with low- and middle-income countries experiencing multiple impacts simultaneously (see Figure 1). ${ }^{12}$ 


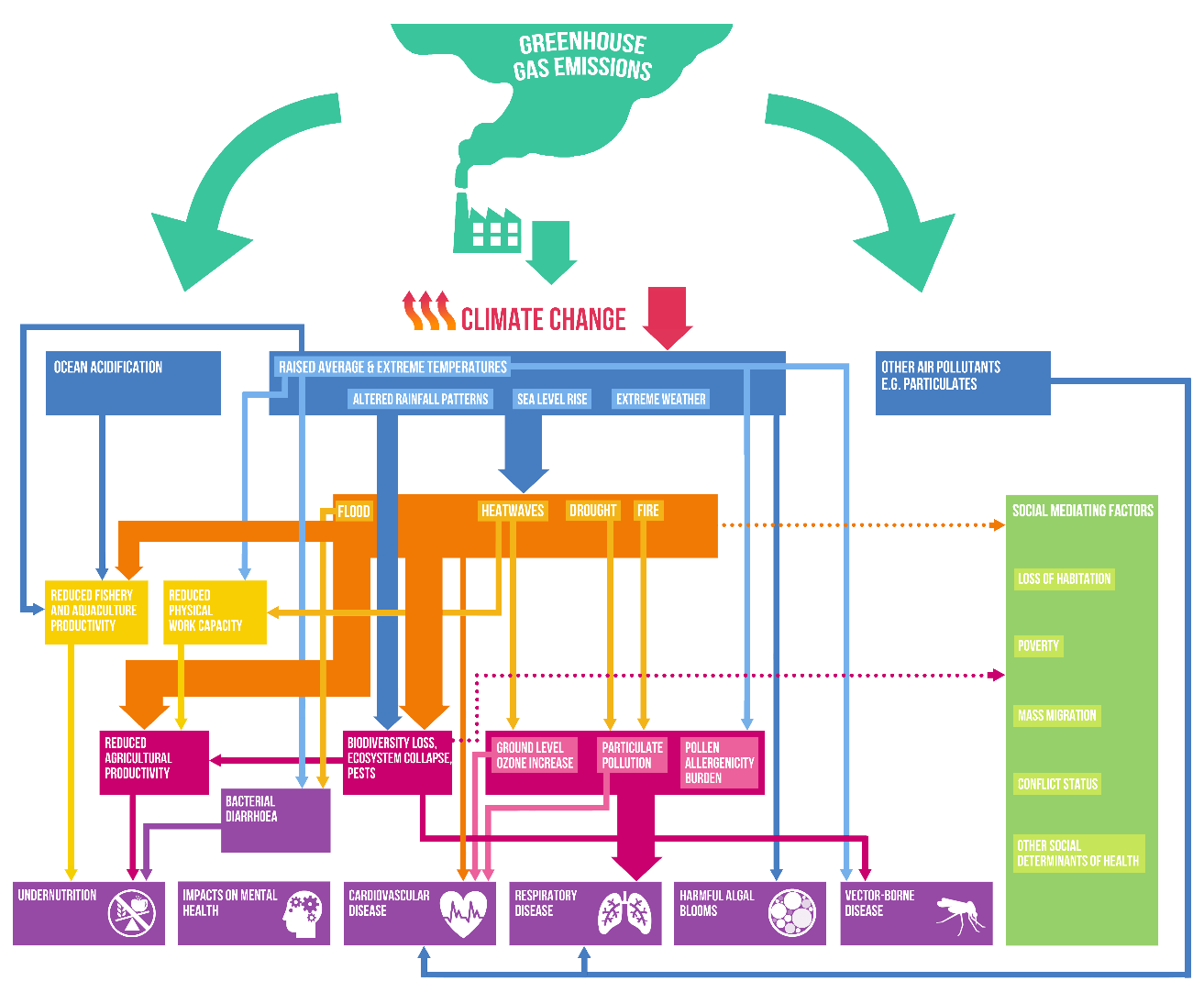

Figure 1. The health impacts of climate change (source: Lancet Commission, 20155)

The Rockefeller Foundation-Lancet Commission on Planetary Health described how sustained human health and development depend on flourishing natural systems. This Commission and others have drawn attention to the fact that human activities are breaching environmental limits across a range of areas, driving terrestrial and marine biodiversity loss, ocean acidification, stratospheric ozone depletion, soil degradation, and other potentially irreversible processes. ${ }^{13,14}$

At the international level, the Paris Agreement provides the framework for future international cooperation and national action on climate change. Modelling suggests that the full implementation of all national government pledged mitigation actions would limit global average warming to around $2.7^{\circ} \mathrm{C}$ by 2100 ; an improvement on the high-end $4.8^{\circ} \mathrm{C}$ or more scenario, but substantially higher than the agreed United Nations target of "well below $2.0^{\circ} \mathrm{C}$ "..$^{15}$

Responsibility for the implementation of the Paris Agreement now falls to national governments. The next 15 years, from 2016 to 2030, are a crucial window that will determine the trajectory of climate change and human development for the coming century. As part of this transition, countries will have to shift from an understanding of climate change solely as a threat, to one which embraces the response to climate change as an opportunity for human health and wellbeing. Tracking and communicating this shift will be the central focus of the Lancet Countdown: Tracking Progress on Health and Climate Change. 


\section{Aims of the Lancet Countdown on Health and Climate Change}

The Lancet Countdown aims to: track the impacts of climate change and the speed of the transition to a decarbonised global economy, a transition that is already underway; analyse and demonstrate the health benefits available; provide a global picture of successes and obstructions in this shift; draw out exemplary case-studies for shared learning; and engage with policymakers and the broader health community to better communicate the opportunities available in responding to climate change both for health and more broadly.

To do this, the Lancet Countdown will report annually on key indicators that reflect progress on health and climate change. Published each year, before the UN Framework Convention on Climate Change's (UNFCCC) international negotiations, the annual Lancet paper will consider global, regional, national, and, on a selective basis, city level trends. Five interrelated thematic working groups will cover different aspects of the relationship between health and climate change, including: the health impacts of climate change; health resilience and adaptation; the health co-benefits of mitigation; economics and finance; and political and broader engagement.

The Lancet Countdown is an international, multi-disciplinary research collaboration between academic institutions and experts across the world. Where the 2015 Lancet Commission existed as a partnership primarily between European and Chinese academics, the Lancet Countdown will build on these foundations to be more global, both in expertise and outlook.

\section{Indicators of Progress: A Call for Input and Engagement}

The work of the Lancet Countdown is divided into five working groups, each of which will be responsible for their own set of indicators. Table 1 and the rest of this paper outlines proposed indicator domains for these working groups. These are presented for consultation with varying degrees of certainty, ranging from the presentation of a specific indicator, through to the description of a broad domain within which a number of indicators might function.

The ongoing framing and selection of indicators to mark the progress to a low-carbon and climate resilient society could take a number of forms, such as focusing on the interactions between society and environment (as seen in the DPSEEA framework, adapted in Appendix 1); or vulnerability, risk and adaptive capacity to climate change. ${ }^{16-18}$ The selected indicators will need to address the challenges of representing spatial and temporal factors in a summarized form. The framing that will be used to select indicators as part of the Lancet Countdown is primarily from the health perspective. In turn, the focus is on those indicators that capture the greatest effects that climate change has on health; the anthropogenic drivers that have the greatest contribution to climate change and the measures and actions that would substantially reduce the effects climate change or yield health co-benefits of mitigation policies.

The proposed indicator domains reflect a pragmatic need to capture markers of progress in the key interactions between health and climate change using the best available data, and those that can be translated to the health community and more widely. They were developed through an iterative process, following an initial, broad consultation process. This sought input from a wide variety of experts working in the field. These were further discussed and refined by the Lancet Countdown's academic working groups at a series of multidisciplinary meetings throughout 2016. Each proposed 
indicator domain was assessed for its ability to cover a unique part of the relationship between health and climate change; potential data availability; feasibility given current resource constraints; applicability to countries across a variety of resource settings; and policy relevance.

This collaborative process is intended to work closely with other monitoring initiatives, such as the information being collected under the WHO's Climate and Health Country Profiles, the SHUE (Sustainable Healthy Urban Environments) project, the Sendai Framework, and the ClimateWorks Foundation's Carbon Transparency Initiative. ${ }^{19-22}$ It will also look to draw on the UN SDGs where appropriate. The potential links between these initiatives and the Lancet Countdown's indicator domains have been summarised in Appendix 2. Where relevant cross-over exists, the Lancet Countdown will look to incorporate this data into its work to provide a more complete, and standardised overview.

This paper marks the beginning of an external consultation process, to further refine the suggestions below. Indeed, it is expected that, the indicators and metrics used will continuously evolve to make use of emerging evidence and data availability. To this end, the Lancet Countdown is committed to maintaining an open approach to further developing its work programme, inviting external input and actively consulting over the coming months. The research collaboration welcomes engagement with new academic partners, with the expertise and capacity to make substantial contributions to the final indicator process. The collaboration is also open to developing new research projects on as-yet neglected areas of health and climate change, with the possibility to jointly seek additional funding and capacity for this work in future. We invite direct input on the content, methods, and data for the proposed indicators and indicator domains, as well as proposals for new partnerships, on the Lancet Countdown website.

Thematic Working Group

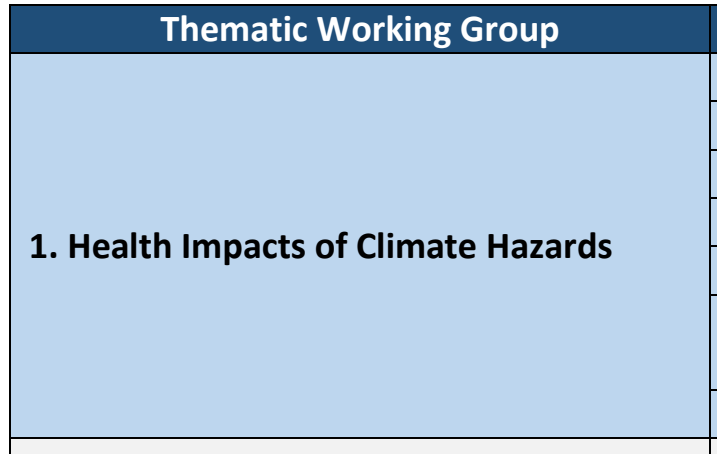

2. Health Resilience and Adaptation

\section{Health Co-Benefits of Mitigation}

\section{Indicator Domains}

1.1 Exposure to temperature change

1.2 Exposure to heatwaves

1.3 Change in labour productivity

1.4 Exposure to flood

1.5 Exposure to drought

1.6 Changes in the incidence and geographical range of climate-sensitive infectious diseases across sentinel sites

1.7 Food security and undernutrition

2.1 Integration of health into national adaptation plans

2.2 Climate services for health

2.3 Adaptation finance for health

3.1. Coal phase-out

3.2 Growth in renewable energy

3.3 Access to clean energy

3.4. Energy access for health facilities

3.5 Exposure to ambient air pollution

3.6 Deployment of low-emission vehicles and access to public transport

3.7 Active travel infrastructure and uptake

3.8 Greenhouse gas emissions from the food system and healthy diets

3.9 Greenhouse gas emissions of healthcare systems 


\begin{tabular}{|c|c|}
\hline \multirow{7}{*}{ 4. Economics and Finance } & 4.1 Change in annual investment in renewable energy \\
\hline & 4.2 Change in annual investment in energy efficiency \\
\hline & $\begin{array}{l}4.3 \text { Low-carbon technology patent generation and } \\
\text { innovation }\end{array}$ \\
\hline & $\begin{array}{l}4.4 \text { Valuing the health co-benefits of climate change } \\
\text { mitigation }\end{array}$ \\
\hline & 4.5 Direct and indirect fossil fuel subsidies \\
\hline & 4.6 Coverage and strength of carbon pricing \\
\hline & 4.7 Equity of the low-carbon transition \\
\hline \multirow{5}{*}{ 5. Political and Broader Engagement } & 5.1 Public engagement with health and climate change \\
\hline & 5.2 Academic publications on health and climate change \\
\hline & $\begin{array}{l}5.3 \text { Inclusion of health and climate change within medica } \\
\text { and public health curricula }\end{array}$ \\
\hline & $\begin{array}{l}5.4 \text { Health and climate change in the UNFCCC and UNGA } \\
\text { high-level statements }\end{array}$ \\
\hline & $\begin{array}{l}5.5 \text { Implementation and estimated health benefits of the } \\
\text { Nationally Determined Contributions (NDCs) }\end{array}$ \\
\hline
\end{tabular}

Table 1. Proposed indicator domains for the Lancet Countdown: Tracking Progress on Health and Climate Change. Importantly, these indicator domains are heterogeneous in nature - some reflect outcomes (GHG emissions or health) and others reflect process indicators with both direct and indirect links to climate change. Additionally, some can be modelled at a global or national level, whereas others reflect location-specific issues and would depend on data collection at sentinel sites.

\section{Health impacts of climate change}

The health effects of climate change are projected to become increasingly severe in the future, and threaten to undermine the last half-century of gains in public health and development. ${ }^{3,5}$ These effects are unevenly distributed within and between countries, with all risks having important social, economic, and geographical mediating factors. ${ }^{19}$ The first working group of the Lancet Countdown proposes seven indicator domains to be considered and then tracked.

\section{1-1.5: Human exposure to extreme weather}

These domains will use observed meteorological data to create indicators of exposure to extremes of weather across five areas: annual mean temperature change; heat index relevant for outdoor labour productivity; heatwave; drought; and flood risk. This data will be complemented by a review of the detection and attribution studies linking climate change to specific extreme weather events that have affected human health. These indices are deliberately similar to those presented in the Lancet Commission for consistency and transparency. ${ }^{5}$ For the Lancet Countdown, we will focus on metrics calculated from observational data rather than climate model projections. However, we aim to maintain comparability between these metrics for the monitoring of progress, and the exposure metrics implied by the future projections presented in the Lancet Commission report. ${ }^{5}$

Mean temperature increase and changes in the severity and frequency of heatwaves bring substantial and potentially fatal health risks to most populations. ${ }^{3,23}$ These include particularly exposed individuals (i.e. those engaged in outdoor physical labour), and individuals with reduced 
capacity to maintain physiological homeostasis, such as the infirm, neonates, or the elderly. The direct relationship between extremes of heat and heat-related morbidity and mortality is well established, as is the relationship between indicators of thermal stress such as wet bulb globe temperature (WBGT), and reductions in outdoor labour productivity, to a lesser extent. ${ }^{24}$ Examples of direct and indirect health effects were seen in the 2010 Russian heatwave, which resulted in approximately 11,000 excess deaths from heat and poor air quality from subsequent forest fires. ${ }^{25}$ The Lancet Countdown will utilise the population related metrics developed from the 2015 Lancet Commission to calculate the mean warming experienced by people. ${ }^{5}$ It will also make use of the index proposed by Jacob et al., defining a heatwave as more than three consecutive days where minimum temperature exceeds the $99^{\text {th }}$ percentile for the recent past. ${ }^{26}$ In addition, changes in labour productivity will be modelled using WBGT, which has been used to identify thresholds of heat stress. $^{27}$

The fourth and fifth indicator domains will follow human exposure to flood and drought. Here, flood refers to meteorological floods, related to rain, storm surges, and sea level rise, rather than due to tsunamis or volcanic eruptions, melting snow and ice. Drought refers to meteorological drought, so a deficit of precipitation, rather than other forms of drought, such as water depletion caused by increasing demand. ${ }^{28,29}$ Observational data suggests that many regions demonstrating rising frequency of meteorological drought over the past 60 years overlap with crucial agricultural zones and regions expecting rapid population expansion in sub-Saharan Africa and South Asia. ${ }^{30,31}$ Analysis in the 2015 Commission projected an additional 1.4 billion person drought exposure events per year by 2100 , as a result of population change and climate change. ${ }^{5}$

Of particular importance, is the effect that climate change will have on mental health and wellbeing, an issue which is often amplified in low-resource settings which lack the protective social and public health institutions. The Lancet Countdown is currently exploring options to track the mental health impacts of climate change.

\section{6: Human Exposure to Infectious Disease}

Infectious diseases make significant contributions to the global burden of disease, and many infectious diseases, their vectors and/or reservoirs, are influenced directly or indirectly by climate. ${ }^{32}$ Distributions and impacts of infectious diseases are already responding to the various dimensions of climate change so far observed, with projections that this will worsen for many infectious diseases in future. ${ }^{33-35}$

Given existing information about climate-sensitive infectious diseases, we will derive a shortlist of 'sentinel' diseases or disease groups to road-test the indicator protocol, and then expand the list to include other relevant infectious diseases and following wider input and consultation with infectious disease experts. Examples from three key groups will be tracked: food-borne diseases, and vectorborne and parasitic diseases/zoonotic diseases. ${ }^{36}$ Each of these groups, and specific diseases within each group, are likely to be affected by climate change in diverse ways. Our aim is to place a finger on the pulse of these impacts at a global scale and facilitate trend tracking through time. For this indicator domain, we will thus leverage surveillance and research networks that monitor and synthesise existing data to model changes in climate change relevant infectious disease impacts and/or risks and exposure. ${ }^{37-39}$ This process will identify sentinel sites (as comprehensive monitoring is not feasible) across a range of geographies. We would welcome suggestions of suitable sites and diseases. 
A number of sub-indicators will be derived for this purpose, broadly covering the areas of outbreaks, occurrence and spread (of disease, causative agents, or vector or reservoir species), and prevalence and incidence, providing a picture of changing trends in exposure to, and impacts from infectious diseases due to climate change. Four focal metrics proposed for each of these indicators include 1) change in cases observed and predicted in the human population, 2) changes observed or predicted in geographical or temporal extent 3 ) observed or predicted changes in environmental suitability for sentinel pathogens, vectors or reservoirs, 4) changes in other environmental exposures and confounding factors.

\section{7: Food security and undernutrition}

Having reliable access to sufficient, affordable and nutritious food can be negatively affected by climate change in many ways. This ranges from the direct impact of drought, flood and heat on harvest yields, through to the health and social impacts of climate change, resulting in unhealthy populations unable to farm or work enough to earn money to purchase food. Furthermore, food trade may be disrupted due to infrastructure damaged by climate shocks. ${ }^{40}$ Populations in lowincome countries reliant on rain-fed agriculture are often particularly vulnerable to climate change and weather shocks. These disproportionately affect the availability and cost of staples, as a result of unreliable access to international markets and low food stocks being unable to buffer price spikes. ${ }^{40}$

Whilst the health implications of food insecurity are local, international and national drivers are important. ${ }^{41}$ Further, measures to ensure climate-resilient food systems also improve food security, public health and community development. ${ }^{40}$ Climate-related food security indicators can address direct availability of food (agricultural production), households' ability to purchase food (rural and urban poverty relative to food prices), and resilience to shocks (food stocks and international trade in grains). The seventh proposed indicator domain will focus on food price indices and food stocks as a proxy for food affordability and availability. Other environmental and socioeconomic factors are likely to be key to understanding food security and undernutrition. To this end, the Lancet Countdown will seek partnership with external activities to fully address this interaction.

\section{Health Resilience and Adaptation}

Adaptation interventions designed to minimise the health impacts of climate change are already required, today. The second working group of the Lancet Countdown will focus on the design and deployment of adaptation and resilience interventions. It will particularly draw on data collected for the WHO/UNFCCC Climate and Health Country Profiles, including responses to surveys from national Ministries of Health. ${ }^{42}$

\section{1: Health adaptation planning}

Past and ongoing human influence on the atmosphere means we are now committed to climate change for several decades to come. Health and related systems, such as water, sanitation and nutrition, will need to become more resilient and adapt to changing climate conditions, in order to continue to protect and promote health in a changing climate. WHO, UNFCCC and other international agencies are supporting countries to develop the health components of national 
adaptation plans, and promoting a comprehensive approach to build resilience into the building blocks of health and other relevant systems. ${ }^{43,44}$ This eventual indicator will use the monitoring systems established for SDG indicator 13.2.1, monitoring submissions to the UNFCCC, and survey responses from national Ministries of Health, to track the number of countries that have developed a health adaptation plan, the range of functions covered, and the extent of implementation.

\section{2: Climate services for health}

Informed adaptation and sustainable development requires the use of climate information for evidence-based decision-making in the health sector. This depends fundamentally upon the availability of relevant, high quality climate and environmental observations, institutional and human capacity to transform climate data into reliable, and relevant climate products and services. The availability, access to, and use of climate services are thus a cornerstone for health adaptation. This should be monitored as an indicator of health sector capacity to help anticipate and prepare for climate risks, appropriately target long- and short-term investments, and avoid potentially maladaptive choices.

For the purposes of the Lancet Countdown, we plan to collaborate with the WMO to conduct a periodic survey of National Hydrological and Meteorological Services, to monitor the demand, availability and provision of climate information services provided to the public and national health authorities. Categories of services surveyed may include: sharing of historical climate and hydrological observations, tailored forecasts or monitoring for exposure to hazardous air quality, pollen, extreme heat, floods and storms; or provision of tailored climate scenarios and impact projections. This will also be cross-referenced with WHO surveys of national Ministries of Health to measure the extent to which countries use this information to inform health surveillance and to develop early warning and response systems. An additional dimension to this indicator domain could involve analysing national expenditure on climate information services.

\section{3: Adaptation finance for health}

Health is widely recognized as a priority for adaptation. For example, over $95 \%$ of Least Developed Countries (LDCs) identified health as a priority in their National Adaptation Programmes for Action. ${ }^{45}$ However, this is not yet reflected in financial flows, with less than $1.5 \%$ of international climate finance for adaptation has been directed to projects specifically addressing health. ${ }^{42}$ This proposed indicator domain will use information from monitoring systems of multilateral and bilateral climate finance, including SDG indicator 13.a.1, as well as survey responses from health ministries, to measure investment of international and domestic resources in health adaptation to climate change.

\section{Health co-benefits of mitigation}

The existence of ancillary health benefits (co-benefits) of climate change mitigation policies provides a powerful incentive to accelerate policy change, since these benefits are experienced in the nearterm, as opposed to the long-term benefits of climate change mitigation. As noted, however, such benefits are not automatic, and care is needed to avoid unintended adverse consequences for health. In order to assess progress in climate change mitigation and the potential resultant ancillary health effects (mainly co-benefits), the third working group envisions tracking nine indicators across four systems - energy, transport, food, and healthcare. 
Here, relevant categories of data include trends in GHG and short lived climate pollutant (SLCP) emissions, indicators relevant to the pathways by which health co-benefits are achieved (air pollution exposures, transport-related physical activity patterns, and dietary survey data), and regulations (e.g. restrictions on polluting vehicles, energy sources, and energy performance) in sectors that are also responsible for GHG/SLCP emissions. Trends in GHG emissions by country can be assessed through the UNFCCC reporting mechanisms and notification is subject to new reporting requirements.

\section{1-3.5: The Energy Sector}

The energy sector (both production and use) represents the largest single source of anthropogenic GHG emissions globally, producing an estimated two-thirds of such emissions. ${ }^{15,46}$ It is also the predominant source of air pollution, with almost all globally produced sulphur dioxide and nitrogen oxide emissions, as well as around $85 \%$ of particulate matter, being produced by energy production and energy use in buildings, industry and transport. ${ }^{47}$

\section{1: Coal phase-out}

Coal use comprises $29 \%$ of total global fuel use. ${ }^{48}$ Globally, coal is used to generate $40 \%$ of electricity and, among all energy sources for electricity production, coal-fired generation contributes most (50\%) to ambient air pollution (and consequently to adverse impacts on health) as well as to $\mathrm{CO}_{2}$ emissions. ${ }^{49}$ Coal is responsible for approximately $60 \%$ of global sulphur dioxide emissions. Until recently, coal use grew steadily through to 2014 , with China being the major user (over $80 \%$ of global growth since 2000 and approximately $50 \%$ of total global use). ${ }^{49}$

Counts of the number and capacity of coal-fired plants, their use of coal, and their emissions, can be monitored, but more informative would be estimates of the loss of life expectancy attributable to the contribution of coal-fired combustion to ambient air pollution. The estimation of such burdens is theoretically possible, but depends on high quality emissions inventory data, and air pollution modelling of source contributions to human exposure. This is feasible in data rich (primarily OECD) settings, but not universally. The International Energy Agency (IEA) produces Market Reports on coal use and forecasts for both the OECD and non-OECD countries. ${ }^{49}$ The data are derived from country level estimates of installed capacity, fuel consumption or power generation; the fuel mix of coal and emission standards will be used to derive estimates of coal-related air pollution. Initially, this will be feasible in specific geographical locations, with ambition to expand the work globally.

\section{2: Growth in renewable energy use}

Globally, renewable energy from wind, solar thermal, photovoltaic, hydro, tidal, geothermal, biofuels and waste comprised $14 \%$ of total primary energy supply, $22 \%$ of global electricity generation, and accounted for nearly half of the new generation capacity added in $2014.48,50$ Renewable energy offers a number of important potential mechanisms for addressing climate change and improving health. Most forms of renewable energy produce no direct emissions related to electricity generation (with the exception of biomass) and therefore help alleviate air pollution exposure. Renewables can also scale and be deployed as decentralised systems, providing greater penetration and provision of modern energy to hard-to-reach populations and health facilities. 
Renewable energy growth is primarily measured in terms of capacity and total final energy consumption (TFEC). The Lancet Countdown plans to use this as an indicator of growth in renewable energy, using the IEA and International Renewable Energy Agency's (IRENA) regularly published estimates.

\section{3: Access to clean energy}

Access to adequate and clean energy supplies in the household offers numerous benefits to health, and improved life expectancy. ${ }^{8,51}$ In 2013, the IEA estimated that around 1.2 billion people do not have access to electricity and around 2.7 billion people rely on burning unsustainable and inefficient solid fuels for cooking and heating. ${ }^{48}$ The household air pollution that results from these fuels and other sources has an attributable impact of around 4.3 million deaths annually, related to pneumonia, stroke, lung cancer, stroke, heart disease, and COPD. ${ }^{52}$ Although access to electricity is growing, with the current average national electrification rate being $83 \%$, there is enormous variability, with urban access to electricity as low as $1-4 \%$ in South Sudan, Liberia, and Central African Republic. $^{53,54}$

For the purposes of the Lancet Countdown on Health and Climate Change, the IEA and World Bank produce national statistics on metrics of energy use based on surveys and data provided by member countries and their own research. These metrics include: energy use per capita, percentage of population with access to non-solid fuels, and percentage of population with access to electricity. The SDG indicators focus on the latter two metrics of energy access. The Lancet Countdown is also exploring the feasibility of monitoring the expansion of micro-grids in low-resource settings, as an important component of the expansion of renewable energy.

\section{4: Energy access for health facilities}

Access to energy is crucial for the delivery of healthcare. Providing adequate lighting, cooling of medicines, controlling indoor thermal exposure, and hot water for washing and sterilization and clinical procedures rely on a consistent delivery of energy. Among low-income countries, healthcare facilities struggle to ensure access to consistent and affordable energy. A review of healthcare facilities in a number of sub-Saharan countries showed on average $26 \%$ of those facilities having no access to electricity; $28 \%$ had reliable access to electricity, while $7 \%$ relied solely on generators. ${ }^{55}$ The WHO have proposed a 'multi-tier metric' for assessing electricity access among healthcare facilities and include peak power capacity, daily energy capacity, duration of supply, evening peak hours supply, affordability, quality, reliability, operational sustainability, and environmental sustainability and health. ${ }^{56}$ This metric has yet to be operationalised, but the Lancet Countdown will draw on this measure for reporting on the healthcare sector.

\section{5: Exposure to ambient air pollution}

An estimated 18,000 people die every day due to air pollution exposure, making it the world's largest single environmental health risk. This public health emergency is particularly pertinent in urban areas, but also affects non-urban populationshere. ${ }^{57}$ As Figure 2 shows, the vast majority ( $90 \%)$ of Europeans living in urban areas and almost all (98\%) of those living in cities in low- and middle-income countries are exposed to air pollution levels in excess of WHO guidelines. ${ }^{47,58}$ 
Moreover, current evidence suggests health effects at concentrations below guideline levels, without threshold, so that health benefits can be expected the more pollution is reduced regardless of initial concentrations.

Figure 1.7 $\triangleright \quad$ Average annual outdoor $\mathrm{PM}_{2.5}$ concentrations in selected urban areas

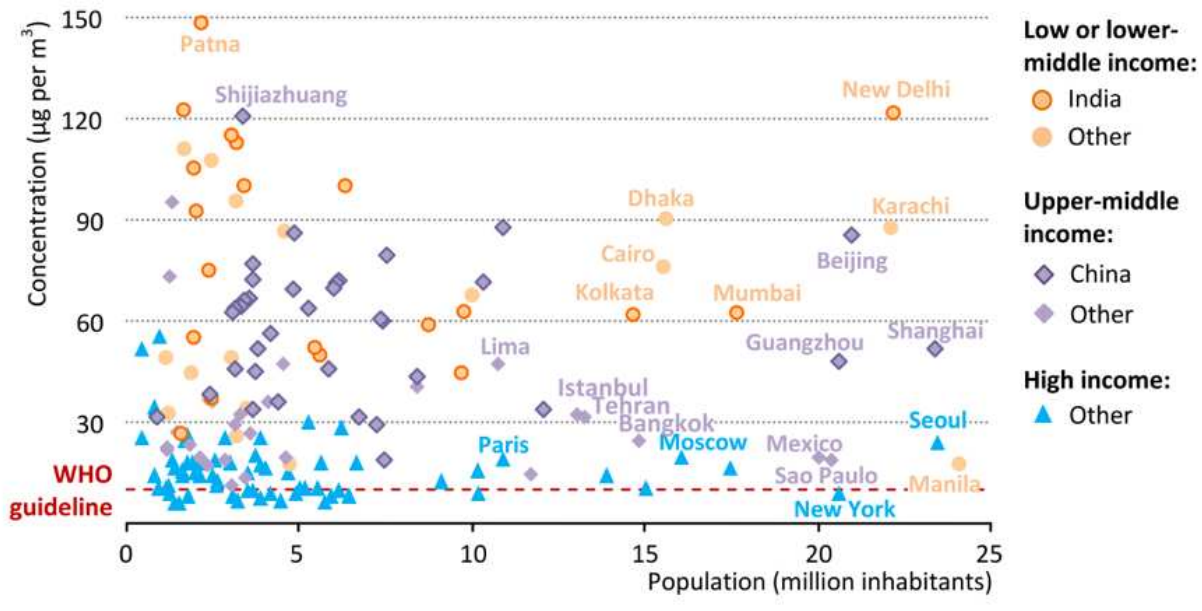

Sources: WHO (2016) Global Urban Ambient Air Pollution Database; Demographia (2015) for population country groups per income based on World Bank (2016).

Figure 2 - Average annual outdoor PM2.5 concentrations in selected urban areas (IEA, 2016, Energy and Air Pollution) ${ }^{47}$

The WHO's Urban Ambient Air Pollution Database now has annual mean outdoor concentrations of $\mathrm{PM}_{10}$ and $\mathrm{PM}_{2.5}$ for almost 3,000 cities. As part of the Lancet Countdown, this database will provide an important data source for cities. We propose to track a number of indicators of (urban) air pollution, primarily annual mean $\mathrm{PM}_{2.5}$ and/or $\mathrm{PM}_{10}$ together with selected other pollutants (e.g. $\mathrm{NO}_{2}$ ), using data for individual cities and, where feasible, population weighted averages for other geographic scales.

\section{6-3.7: The Transport Sector}

Transportation systems - including road vehicles, rail, shipping, and aviation - are a key source of GHG emissions, contributing $14 \%$ of global GHG emissions in $2010.47,48,59$ It is also a major source of air pollutants, including particulate matter (PM), nitrogen oxides $\left(\mathrm{NO}_{\mathrm{x}}\right)$, sulphur dioxide, carbon monoxide, and volatile organic compounds, and, indirectly, ozone $\left(\mathrm{O}_{3}\right)$. The IEA estimates over half of global $\mathrm{NO}_{x}$ emissions are produced by the transport sector. ${ }^{47}$ 


\section{6: Deployment of low-emission vehicles and access to public transport}

Switching to low-emission transport systems is an important component of climate mitigation and will help reduce concentrations of most ambient air pollutants (though counterintuitively in some settings, may lead to greater concentrations of ozone because of the 'titration effect' of $\mathrm{NO}_{2}$ ). ${ }^{5}$ Personal exposure to traffic-related air pollution is a function of both ambient concentrations (a function of vehicle technology and other factors) and time activity patterns. ${ }^{60-64}$ The IEA maintains a technical-economic database that includes detailed transport activity, vehicle activity, energy demand, and well-to-wheel GHG and pollutant emissions. ${ }^{65}$ The Global Electric Vehicle Outlook report tracks sales of electric vehicles, and the International Council on Clean Transportation maintains a set of data tables, comparison charts, and a conversion tool for comparing passenger vehicle fuel standards. These types of databases and methods will provide the quantitative backing to this indicator domain for the Lancet Countdown, which will track clean transport technology (e.g. electric vehicles) deployment and sector-specific emission factor trends at a variety of geographic scales.

\section{7: Active travel infrastructure and uptake}

While decarbonizing the vehicle fleet is essential for meeting climate mitigation targets and improving urban air quality, in most settings encouraging the greater uptake of active travel (walking and cycling) for shorter journeys offers the greater opportunity for public health benefit. This is because active travel can lead to appreciable improvement in the levels of physical activity at population level, with all the attendant benefits in terms of reduced risk of cardiovascular disease, selected cancers, dementia, and diabetes, and improvement in mental well-being. Whilst these benefits may be partly offset by increases in exposure to road danger and, in some settings, higher exposure to ambient air pollution, the injury risks can be moderated by policies to improve road safety. ${ }^{7}$

Indicators to be considered include (where available) proportion of journeys and distance taken on foot and bicycle in major urban areas. Such data require travel surveys, which are routinely implemented and with comparable methods only in selected (mainly high income) settings. In these cases, data on the duration of active travel, and the number of road crashes that occur could be collected. The contribution of change in active travel to population health could be computed given other population health and activity data, but to date, has seldom been assessed outside research studies.

\section{8: Greenhouse gas emissions from the food systems and healthy diets}

Sub-indicators under this heading will consider how food consumption and production affects and is affected by climate change, and the additional impacts this has on health. There is growing evidence on the benefits to health from more sustainable food systems and dietary change.

\section{Consumption}

Although all foods contribute to the emission of climate pollutants to different extents, among those with the greatest GHG footprints are meat and dairy products. These also contribute to water scarcity, land use change and erosion, and ultimately increase risks for cardiovascular disease, and 
some cancers in the case of red and processed meats. ${ }^{66}$ Emissions per unit protein produced are especially high for ruminants (cattle, goat and sheep), as compared to pork and poultry production. Although desirable to track trends in consumption patterns - especially of meat, dairy and vegetables - the calculation of associated GHG emissions in particular, is complex, and so too the computation of health effects. In certain countries, the contribution of livestock to GHG emissions may be less substantial than in most high-income countries. Additionally, in many low- and middleincome countries, animal products may be important, providing an invaluable source of nutrients particularly to children and pregnant women. ${ }^{67}$ We propose measures of consumption of meat, dairy, vegetables and legumes, derived from standardized population dietary surveys and food diaries could be used to track consumption changes. By converting these datasets into per capita quantities, these trends could be tracked annually. However, data from (nationally) representative surveys is not widely available. Case-studies may therefore be a useful tool for highlighting the health and climate benefits of reduced meat and dairy consumption.

\section{Production}

Agricultural production can be a significant contributor to GHG emissions. As such, there is clear room for improvement in water, carbon and nitrogen management in over-fertilized regions (e.g. China and India) to reduce GHG emissions and water pollution from agricultural lands and enhance environmental sustainability. ${ }^{68}$ For example, it is estimated that in the farmlands of China, a nitrogen use efficiency improvement from $31 \%$ to $50 \%$ would cut synthetic nitrogen use by $41 \%$, and GHG emissions by $39 \% .{ }^{69}$ The second element of this indicator domain will track changes in food production and food waste over time and the consequent impacts upon GHG emissions and health. GHG emissions associated with agriculture (including livestock systems and biogeochemical processes) will be quantified using existing models (e.g. DAYCENT or DNDC). ${ }^{70-72}$

An understanding of the potential for multiple environmental factors to affect food systems, and the nuances within and between countries and cultures is needed. Further work will be required to refine indicators for this area, and the scientific community is invited to suggest potential metrics and data sources.

\section{9: Greenhouse gas emissions of healthcare systems}

The health sector is a major contributor to GHG emissions, and has both a special responsibility and significant measurable opportunity to lead by example in reducing its carbon footprint.

Pharmaceuticals, for example, are associated with high levels of avoidable GHG emissions, and there is nearly always scope for savings in transport and procuring goods needed to support the health system. ${ }^{73}$ Such actions have already been demonstrated to deliver health, social, environmental, and economic benefits, both immediate and long term. Calculation of the carbon intensity and emissions of the health sector has been achieved in England and the USA (serially in the former), despite complexities in capturing all inputs to provide comparable data over time, place and sub-sector. ${ }^{74-76}$ For the purposes of the Lancet Countdown, we will collect purposive samples from countries where data are available initially to raise the profile of the topic within the health community locally, nationally, and globally. 


\section{Economics and Finance}

Article 2 of the Paris Agreement establishes the importance of ensuring financial flows consistent with a pathway towards a low-carbon economy. The focus of the Lancet Countdown's fourth working group is on the ways in which flows of finance and economic incentives are developing to accelerate progress on health and climate change. Indicators fall into three broad 'themes': investment in the low-carbon economy; valuing the health co-benefits of mitigation; and pricing the health externalities of fossil fuels.

\section{1 to 4.3: Investing in the low-carbon economy}

Having made the case for a comprehensive response to climate change and the resultant health benefits, three of the proposed indicator domains in working group 4 will track investment in the low-carbon economy; specifically in renewable energy, energy efficiency and innovation.

The first two are closely linked, measuring changes in annual investments in renewable energy and in energy efficiency. In order to decarbonise the global energy system in order to meet the global climate change commitments in the Paris Agreement, whilst simultaneously managing a rise in demand for energy over the coming decades, low-carbon technologies and energy efficiency must account for around $90 \%$ of the $\$ 2.5$ trillion global annual investment required by 2035 . In 2014 , this value stood at $23 \% .{ }^{77}$ Data for annual global investment in renewable energy is compiled and reported by Bloomberg New Energy Finance, which may be presented by the Lancet Countdown. Investment in energy efficiency, however, may be more difficult to track, as there is no standard agreed definition on what constitutes energy efficiency investment, which is carried out by a multitude of agents (often without the use of external finance), and is difficult to disaggregate from other activities. One approach is to estimate energy efficiency investment through modelling techniques. Further work will include discussions with the IEA and other organizations to determine the most appropriate definition to employ and how estimates of investment may be calculated. Estimates of total energy system investment are also published frequently by the IEA, allowing a proportional value for low-carbon technologies and energy efficiency to be calculated.

The third indicator domain here would track innovation in the low-carbon sector, by measuring annual changes in the generation of patents for low-carbon and energy efficient technologies. The data for such calculations may be found in various databases ${ }^{1}$ and would capture the results of a substantial proportion of research and development efforts and funding by both public and private sector actors.

\section{4: Valuing the health co-benefits of climate change mitigation}

Building on work from working group 3, this indicator domain will aim to capture the costs and savings resulting from the health co-benefits of mitigation, across a variety of sectors. In particular, the health-related economic benefits (or costs) of changes in coal-based electricity generation, conventional car sales (i.e. petrol and diesel), and a rise in active transport. It is estimated that the annual value of the health impacts of ambient air pollution, principally caused by coal-based electricity generation and conventional vehicles, is as high as $\$ 3.5$ trillion ( $5 \%$ Gross World Product) in the OECD (plus India and China). ${ }^{78}$ Estimates of health-related economic benefits that result from

\footnotetext{
${ }^{1}$ For example, the European Patent Office Worldwide Database (PATSTAT).
} 
mitigation policies would draw on indicators compiled and reported in working group 3 (e.g. coal phase out rates, low-emission vehicle sales and investment in active transport). Depending on the final form of the indicators presented in working group 3, these indicators may be produced either by relatively simple calculations, or through the use of energy system models that consider air pollution aspects of system developments. If the latter approach is required, further development of in-house air pollution modelling capabilities, or collaboration with other institutions, would be sought. Furthermore, this indicator domain closely relates to the estimating of health benefits of National Determined Contributions (NDCs) under working group 5; these two indicator domains will be jointly refined to ensure they complement each other.

\section{5-4.7: Pricing the health externalities of fossil fuels}

The third and final indicator theme within this working group would measure whether we are 'getting the prices right' to encourage the development of a low-carbon economy, and the heathrelated benefits this brings, including ensuring that that inequities are addressed. Three areas of work would fall under this theme. The first concerns the presence of subsidies (such as tax breaks) for fossil fuel production and consumption, which incentivise their use and increase relative costs of renewable alternatives. In 2014, global fossil fuel subsidies stood at around $\$ 490$ billion - around four times the level of subsidy afforded to the deployment of renewable energy. Although the reform of such subsidies between 2009 and 2014 means that current subsidy levels are around $\$ 117$ billion lower than they would otherwise have been, much more needs to be done. ${ }^{48}$ This is recognised by SDG 12c, the indicator for which, when developed, may be employed here. However, further work will be conducted to determine which definition of fossil fuel subsidies may be suitability employed for the purposes of the Countdown.

The second indicator domain would cover the spread and strength of carbon pricing, which seeks to internalise the 'market externality' of $\mathrm{CO}_{2}$ (and other GHG) emissions globally. Carbon pricing instruments currently cover around $12 \%$ of global GHG emissions, although with wide ranging values (from under $\$ 1 / \mathrm{tCO}_{2} \mathrm{e}$ to around $\$ 130 / \mathrm{tCO}_{2} \mathrm{e}$ ). ${ }^{79}$ This indicator may consist of two elements; the change in (and absolute level of) the proportion of global GHG emissions to which carbon pricing is applied, and the change in (and absolute value of) the weighted-average global carbon price. These data may be drawn directly from, or calculated based on, the World Bank's annual State and Trends of Carbon Pricing report.

The development of such indicators interact with and complement Indicator domains 4.1-4.3. Whilst the reduction of fossil fuel subsidies and increase in the spread and strength of carbon pricing 'pushes' the flow of finances towards the deployment and development of low-carbon and energy efficient technologies and measures, other policies, such as renewable energy subsidies, help to 'pull' finance towards such investments. Indicator domains 4.1 - 4.3 implicitly measure the impact generated by both influences.

What has been presented thus far do not address potential concerns surrounding the equity of the low-carbon transition, with carbon pricing on fuels having potentially regressive impacts. These impacts may be dampened or avoided with the appropriate public policies, such as environmental tax reform (ETR). ETR involves shifting the burden of tax from 'goods', such as labour or environmentally beneficial products or actions, to 'bads', such as pollution. Such a shift in economic incentives may, when well designed, produce a 'double dividend' of environmental improvement with social and economic benefit. ${ }^{80}$ As such, the third indicator domain under this theme concerns 
the use of revenue generated by carbon pricing instruments, with qualitative consideration for the intended end-use of this revenue. Further work is required to determine whether revenue from the reduction of fossil fuel subsidies may also be included in this indicator.

\section{Political and Broader Engagement}

The fifth working group will focus on the broader context within which progress on health and climate change is being made. These indicator domains will track the implementation of political commitments within the UNFCCC, alongside analysis of scientific and public engagement with health and climate change, which both provide background and context for policy implementation.

\section{1: Public engagement with health and climate change}

Globally, public engagement with climate change is mixed. In two surveys of a range of high-income, middle-income and low-income countries, most people considered that climate change was a 'very serious problem' and 'a major threat', and would impact directly on the conditions for health. ${ }^{81,82}$ Asked when they thought climate change would start to substantially harm people in their country (now, in 10 years, in 25 years, in 50 years, in 100 years, never), the majority of respondents in most countries thought that their citizens were being substantially harmed now. Figure 3 presents the proportions responding 'now' and 'in 10 years'. Given that lack of understanding is one of the largest perceived barriers to individual engagement, the finding that framing climate change as a public health issue enhances engagement, is significant. ${ }^{83-85}$

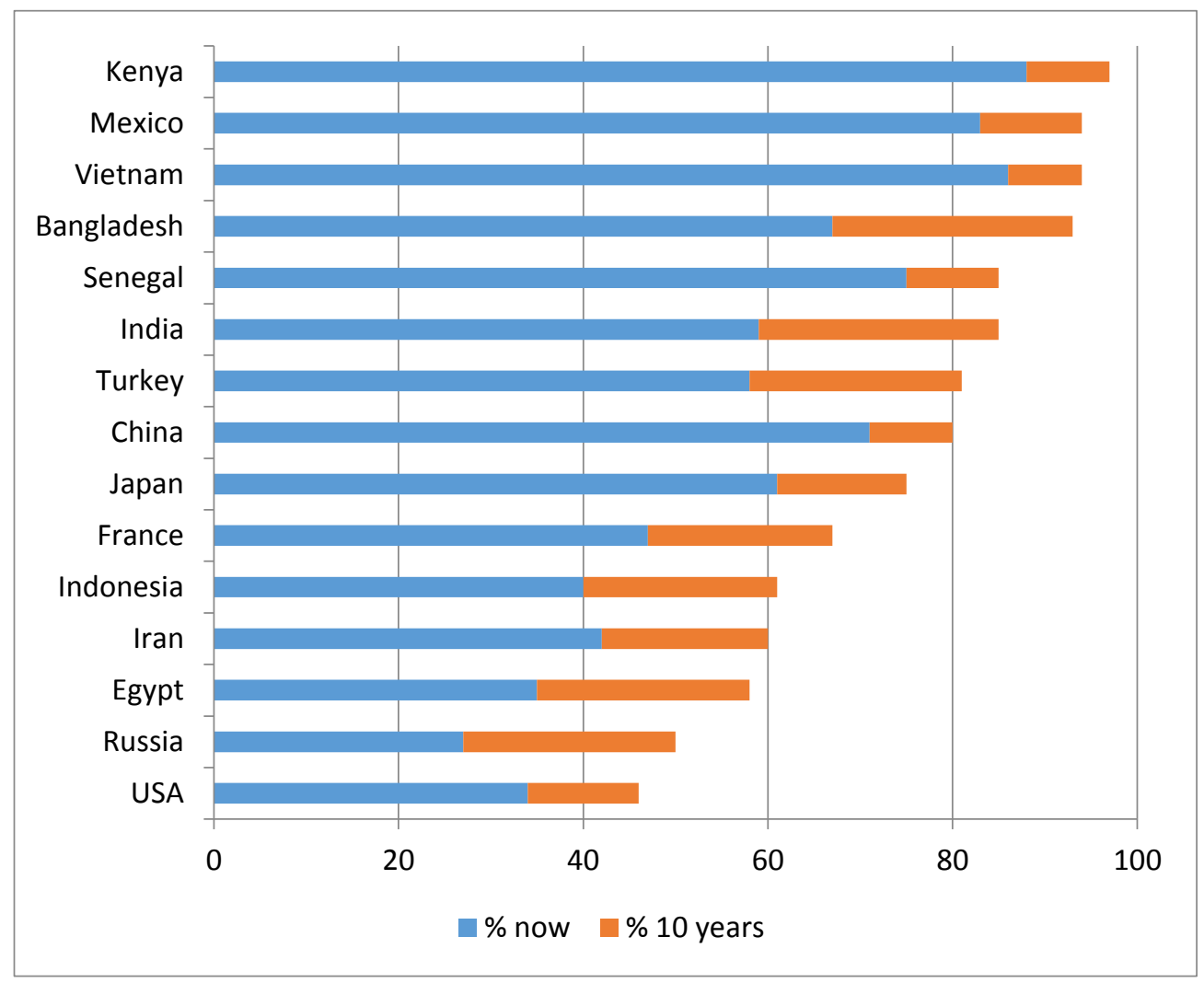

Figure 3. Proportions of the population who regard climate as substantially harming people in their country now or within 10 years (World Bank, 200982) 
The Lancet Countdown will bring together evidence on changes in public understanding relating to health and climate change - more specifically, in terms of perceptions of threats and opportunities in the response. One possible long-term, but resource-intensive approach would be using phoneand online-based public opinion polling techniques across a range of countries and settings. In the interim, the Lancet Countdown proposes to undertake an annual analysis of social media to build a broad understanding of public perceptions, and track the evolution of public engagement and knowledge. The Lancet Countdown's social media analysis will track levels of public engagement with health and climate change over time and identify key events that cause spikes in engagement; whether such spikes result in longer-term engagement; and countries where engagement is particularly high or low.

\section{2 and 5.3: Academic publications on health and climate change and the inclusion of climate change in medical curricula}

The Lancet Countdown will also track scientific engagement with health and climate change. Annual reviews of published scientific articles, using a bibliometric search relating to "climate" and "health" provides a potentially useful indicator, demonstrating research trends and coverage. Historical trends and research gaps including disciplinary and geographical focus could also be explored. This study will provide a more extensive and inclusive overview than previously published reports and reviews, and may also be a useful resource for informing future research funding by gaps and priorities. A study protocol for this scoping review has been written and accepted for publication. ${ }^{86}$

To accompany an analysis of the academic literature, the Lancet Countdown will also follow the extent to which health and climate change is incorporated into the educational curricula of health professionals (initially, medical professionals), around the world. This analysis would determine not just the inclusion of climate change in these curricula, but also the emphasis on these issues (for example, whether this subject matter is mandatory or optional). This may be used to provide background context, rather than as an indicator in its own right.

\section{4 and 5.5: Health and climate change in the UNFCCC and UNGA and implementation and estimated health benefits of the NDCs}

At the international level, the UNFCCC negotiations and the Paris Agreement provide an important framework for mitigation and adaptation policies. Indicator domains 5.4 and 5.5 would both look to provide an overview of the extent to which human health and wellbeing is considered within these political processes. Indicator domain 5.4 would examine the inclusion of health within the transcripts of the high-level statements delivered at the UNFCCC's annual Conference of the Parties, and the UN General Assembly. The former has previously been compiled on an ad hoc basis and would require additional work, but a database of the latter is readily available. The Lancet Countdown would analyse high-level statements to monitor how the inclusion and framing of health and climate change evolves over time. This work could be back-dated to extend this analysis to historical highlevel statements, thus providing a longer time series to analyse.

The final indicator domain for the Lancet Countdown would estimate the health benefits or disadvantages of the NDCs. Initially, the NDCs and subsequent communiques to the UNFCCC will be explored for substantive references and considerations of the relationship between public health and climate change. Over time, it is hoped that the potential health co-benefits of mitigation, from a reduction in air pollution, may be modelled. This would be conducted in a similar way to the analysis 
conducted by the Day, Höhne, and Gonzales in their 2015 assessment. ${ }^{87}$ Many of these changes may be captured by the UNFCCC's NAZCA (non-state actor zone for climate action) process - a potential source for future indicators and monitoring.

\section{Conclusion}

The Lancet Countdown: Tracking Progress on Health and Climate Change is an international, multidisciplinary research collaboration, dedicated to tracking progress on health and climate change from 2016 to 2030.

The Lancet Countdown will be governed by a board comprising the research leads for each working group, and coordinated by a smaller executive team responsible for supporting the working groups to deliver and communicate the academic content. Over the coming months, it will work to establish an international advisory board, to provide strategic direction to the process and assist with policy and stakeholder engagement. This advisory board will be made up of academics and senior health and climate change experts from a broad range of geographies.

The indicators and indicator domains proposed in this paper are intended to form the foundation of our process, and will be refined and developed further over the coming months and throughout the Lancet Countdown's process. We invite ongoing direct input on the content, methods, and data of each of these, through the forms available on the Lancet Countdown website.

\section{Contributors}

The Lancet Countdown: tracking progress on health and climate change is an international academic collaboration that builds on the work of the 2015 Lancet Commission on health and climate change, and is convened by The Lancet. The Countdown and the work for this paper was conducted by five working groups, which were responsible for the design, drafting, and review of their individual sections. All authors contributed to the overall paper structure and concepts, and provided input and expertise to the relevant sections. Authors contributing to Working Group 1: W Neil Adger, Peter Cox, Michael Depledge, Anne Johnson, Lu Liang, Mark Maslin, Kris Murray, and Elizabeth Robinson. Authors contributing to Working Group 2: Sonja Ayeb-Karlsson, Peter Byass, Diarmid Campbell-Lendrum, Paula Dominguez-Salas, Delia Grace, Ilan Kelman, Sari Kovats, Georgina Mace, Karyn Morrissey, Tara Neville, Joy Shumake-Guillemot, and Yongyuan Yin. Authors contributing to Working Group 3: Michael Davies, Andy Haines, Ian Hamilton, Melissa Lott, Robert Lowe, Tadj Oreszczyn, Paolo Vineis, Paul Wilkinson, and Jun Yang. Authors contributing to Working Group 4: Paul Drummond and Paul Ekins. Authors Contributing to Working Group 5: Anneliese Depoux, Antoine Flahault, Hilary Graham, Yong Luo, Christine Parthemore, David Pencheon, Maria Nilsson, and Stefanie Schütte. In addition to this, the following authors provided integrating contributions across multiple working groups: Yuqi Bai, Tim Colbourn, Bing $\mathrm{Xu}$, and Chaoqing Yu. The paper was prepared under the general direction of Anthony Costello (Co-Chair), Hugh Montgomery (Co-Chair), Peng Gong (Co-Chair), and Nick Watts (Executive Director), with editorial support from Nicola Wheeler. The findings and conclusions in this article are those of the authors and do not necessarily represent the official position of WHO or the World Meteorological Organization. 


\section{Declaration of Interests}

The Lancet Countdown's work is funded by an unrestricted grant from the Wellcome Trust. The Lancet Countdown covered travel costs for meetings related to the development of the paper. Three of the authors (NWa, ML, and NWh) were compensated for their time while working on the Lancet Countdown's drafting and development. HG has received an ESRC grant ES/L003015, Health of Populations and Ecosystems (HOPE), outside the scope of the submitted work. HM is a board member of the UK Climate and Health Council and the Energy and Climate Intelligence Unity, and is developing an air pollution mask (which represents no conflict of interest). NWa is the Director of the UK Health Alliance on Climate Change. AJ is a Governor at the Wellcome Trust, and a member of the Adaptation Sub-Committee of the Committee on Climate Change. TO has received an EPSRC grant (EP/K011839/1) for the RCUK centre for energy epidemiology, outside of the submitted work. $P D, P E$, and $M L$ are at The Institute for Sustainable Resources (UCL), which receives funding from BHP Billiton, outside of the submitted work. $A D, A F$, and $S S$ have received grants from Sanofi, outside of the submitted work. WNA, SAK, YB, PB, DCL, TC, PC, MDa, MDe, PDS, DG, AH, IH, IK, SK, LL, RL, YL, GM, MM, KMo, KMu, TN, MN, TO, CP, DP, ER, JSG, PV, PW, BX, JY, YY, CY, PG, HM, and AC declare no competing interests.

\section{Acknowledgments}

The Lancet Countdown would like to thank the Wellcome Trust for its financial and technical support-without which, this research collaboration would not be possible. While carrying out its work, the Lancet Countdown received invaluable technical advice and input from a number of individuals, including Ari Bernstein (Harvard University), Victoria Bignet (Stockholm Resilience Centre), Sarah Chaytor (University College London), Niheer Dasandi (University of Birmingham), Victor Galaz (Stockholm Resilience Centre), Janie Maxwell (University of Melbourne), Slava Mikhaylov (University College London), Neil Morisetti (University College London), Steve Pye (University College London), George Smeeton (Energy and Climate Intelligence Unit), Olivia Stevenson (University College London), Rebecca Taylor (University College London), and Koko Warner (UN Framework Convention on Climate Change). Administrative and communications support was provided by Richard Black (Energy and Climate Intelligence Unit), Pete Chalkley (Energy and Climate Intelligence Unit), Tom Fern (European Climate Foundation), Jack Fisher (Lancet Countdown), and Sarah Hurtes (European Climate Foundation). Researchers at Tsinghua University (YB, PG, YL, BX, JY, YY, and CY) wish to express their gratitude to the Cyrus Tang Foundation for financial support. 


\section{References}

1. World Health Organization. Preventing disease through healthy environments: a global assessment of the burden of disease from environmental risks. Geneva, 2016.

2. Costello A, Abbas $M$, Allen $A$, et al. Managing the health effects of climate change. The Lancet 2009; 373(9676): 1693-733.

3. Smith KR, Woodward A, Campell-Lendrum D, et al. Human Health - Impacts, adaptation and co-benefits. Climate Change 2014: Impacts, Adaptation, and Vulnerability Working Group II Contribution to the IPCC 5th Assessment Report. Cambridge, UK and New York, NY, USA: Cambridge University Press; 2014.

4. Haines A, McMichael A, Epstein P. Global Health Watch: Monitoring Impacts of Environmental Change. The Lancet 1993; 342: 1464-9.

5. Watts N, Adger N, Agnolucci P, et al. Lancet Commission on Health and Climate Change: Policy Responses to Protect Public Health. The Lancet 2015; 386(10006): 1861-914.

6. Friel S, Dangour A, Garnett T, et al. Public health benefits of strategies to reduce greenhouse-gas emissions: food and agriculture. The Lancet 2009; 374: 2016-25.

7. Woodcock J, Edwards P, Tonne C, et al. Public health benefits of strategies to reduce greenhouse-gas emissions: urban land transport. The Lancet 2009; 374(9705): 1930-43.

8. Wilkinson $\mathrm{P}$, Smith KR, Davies $\mathrm{M}$, et al. Public health benefits of strategies to reduce greenhouse-gas emissions: household energy. The Lancet 2009; 374(9705): 1917-29.

9. Markandya A, Armstrong BG, Hales S, et al. Public health benefits of strategies to reduce greenhouse-gas emissions: low-carbon electricity generation. The Lancet 2009; 374(9706): 2006-15.

10. Haines A, McMichael AJ, Smith KR, et al. Public health benefits of strategies to reduce greenhouse-gas emissions: overview and implications for policy makers. The Lancet 2009; 374(9707): 2104-14.

11. IPCC. Summary for Policymakers. In: Field CB, V.R. Barros, D.J. Dokken, K.J. Mach, M.D. Mastrandrea, T.E. Bilir, M. Chatterjee, K.L. Ebi, Y.O. Estrada, R.C. Genova, B. Girma, E.S. Kissel, A.N. Levy, S. MacCracken, P.R. Mastrandrea, and L.L. White ed. Climate Change 2014: Impacts, Adaptation, and Vulnerability Part A: Global and Sectoral Aspects Contribution of Working Group II to the Fifth Assessment Report of the Intergovernmental Panel on Climate Change. Cambridge, United Kingdom and New York, NY, USA: Cambridge University Press; 2014: 1-32.

12. Patz J, Gibbs H, Foley J, Rogers J, Smith K. Climate Change and Global Health: Quantifying a Growing Ethical Crisis. EcoHealth 2007; 4(4): 397-405. 
13. Whitmee S, Haines A, Beyrer C, et al. The Rockefeller Foundation - Lancet Commission on Planetary Health: Safeguarding human health in the Anthropocene epoch. The Lancet 2015;

386(10007): 1973-2028.

14. Rockström J, Steffen W, Noone K, et al. Planetary boundaries: exploring the safe operating space for humanity. Ecology and Society 2009; 14(2).

15. International Energy Agency. Energy and Climate Change: World Energy Outlook - Special Briefing for COP21. Paris, 2015.

16. Organisation for Economic Co-operation and Development. A Core Set of Indicators for Environmental Performance Reviews Paris, 1993.

17. Brooks N. Vulnerability, risk and adaptation: A conceptual framework. Norwich: Tyndall Centre for Climate Change Research, 2003.

18. Hambling $T$, Weinstein $P$, Slaney D. A review of frameworks for developing environmental health indicators for climate change and health. International journal of environmental research and public health 2011; 8(7): 2854-75.

19. World Health Organization, UN Framework Convention on Climate Change. Climate and Health Profiles - A Global Overview. Geneva, 2015.

20. United Nations. Transforming Our World: The 2030 Agenda for Sustainable Development. A/Res/70/1. New York, 2015.

21. UCL Institute for Environmental Design and Engineering. Sustainable Healthy Urban Environments. 2016. https://www.bartlett.ucl.ac.uk/iede/research/projectdirectory/projects/sustainable-healthy-urban-environments (accessed 05 Oct 2016).

22. Reduction UOfDR. Indicators to Monitor Global Targets of the Sendai Framework for Disaster Risk Reduction 2015-2030: A Technical Review. Geneva, 2015.

23. Åström C, Orru H, Rocklöv J, Strandberg G, Ebi KL, Forsberg B. Heat-related respiratory hospital admissions in Europe in a changing climate: a health impact assessment. BMJ Open 2013; 3(1).

24. Kjellstrom $T$, Briggs D, Freyberg C, Lemke B, Otto $M$, Hyatt O. Heat, Human Performance, and Occupational Health: A Key Issue for the Assessment of Global Climate Change Impacts. Annu Rev Public Health 2016; (37): 97-112.

25. Revitch B, Shaposhnikov D. Climate change, heat and cold waves as risk factors of increased mortality in Russia. Ecoforum 2012; 2(10): 122-38.

26. Jacob D, Petersen J, Eggert B, et al. EURO-CORDEX: new high-resolution climate change projections for European impact research. Reg Environ Change 2013; (1-16). 
27. Dunne JP, Stouffer RJ, John JG. Reductions in labour capacity from heat stress under climate warming. Nature Clim Change 2013; 3(6): 563-6.

28. Glantz M, Katz R. When is a drought a drought? Nature 1977; 267: 192-3.

29. Wilhite D, Glantz M. Understanding the Drought Phenomenon: The Role of Definitions. Watern International 1985; 10(3): 111-20.

30. Dai A. Increasing drought under global warming in observations and models. Nature Clim Change 2013; 3: 52-8.

31. Bongaarts J. Development: Slow down population growth. Nature 2016; 530(7591): 409-12.

32. McMichael A, Woodruff R. Climate change and infectious diseases. In: Mayer KH, Pizer HF, eds. The Social Ecology of Infectious Diseases: Academic Press; 2011.

33. Altizer S, Ostfeld RS, Johnson PTJ, Kutz S, Harvell CD. Climate Change and Infectious Diseases: From Evidence to a Predictive Framework. Science 2013; 341(6145): 514-9.

34. Siraj A, Bouma M, Santos-Vega M, Pascual M. Temperature and population density determine reservoir regions of seasonal persistence in highland malaria. Proceedings of the Royal Society B: Biological Sciences 2015; 282(1820).

35. Lafferty KD. Calling for an ecological approach to studying climate change and infectious diseases. Ecology 2009; 90(4): 932-3.

36. Australian Academy of Science. Climate change challenges to health: Risks and opportunities. Canberra, 2014.

37. Victor LY, Edberg SC. Global Infectious Diseases and Epidemiology Network (GIDEON): a world wide Web-based program for diagnosis and informatics in infectious diseases. Clin Infect Dis 2005; 40(1): 123-6.

38. Brownstein JS, Freifeld CC, Reis BY, Mandl KD. Surveillance Sans Frontieres: Internet-based emerging infectious disease intelligence and the HealthMap project. PLoS Med 2008; 5(7): e151.

39. Victor LY, Madoff LC. ProMED-mail: an early warning system for emerging diseases. Clin Infect Dis 2004; 39(2): 227-32.

40. United Nations Environment Programme. Avoiding Future Famines: Strengthening the Ecological Foundation of Food Security through Sustainable Food Systems. Nairobi, 2012.

41. Food and Agricultural Organization, International Fund for Agricultural Development, World Food Programme. The State of Food Insecurity in the World: How does international price volatility affect domestic economies and food security? Rome, 2011. 
42. WHO. Climate and Health Country Profiles - 2015: A Global Overview. Geneva: World Health Organization, 2015.

43. WHO. WHO guidance to protect health from climate change through health adaptation planning. Geneva: World Health Organization, 2014

44. WHO. Health in the Intended Nationally Determined Contributions (INDCs) to the United Nations Framework Convention on Climate Change, 2015. Geneva: World Health Organization, 2016.

45. Manga L, Bagayoko M, Meredith T, Neira M. Overview of health considerations within National Adaptation Programmes of Action for climate change in least developed countries and small island states, 2010.

46. Bruckner T, Bashmakov I, Mulugetta Y, et al. Energy Systems. In: Edenhofer O, PichsMadruga R, Sokona Y, et al., eds. Climate Change 2014: Mitigation of Climate Change Contribution of Working Group III to the Fifth Assessment Report of the Intergovernmental Panel on Climate Change. Cambridge, United Kingdom and New York, NY, USA: Cambridge University Press; 2014.

47. Agency IE. Energy and Air Pollution. World Energy Outlook - Special Report 2016.

48. International Energy Agency. World Energy Outlook 2014. Paris, 2015.

49. International Energy Agency. Medium-Term Coal Market Report 2015: Market Analysis and Forecasts to 2020. Paris, 2015.

50. International Energy Agency. Renewables Information 2016. Paris, 2016.

51. Wilkinson P, Smith KR, Beevers S, Tonne C, Oreszczyn T. Energy, energy efficiency, and the built environment. Lancet 2007; 370: 1175-87.

52. World Health Organization. Burden on Disease from Air Pollution in 2012; 2014. http://www.who.int/phe/health topics/outdoorair/databases/FINAL HAP AAP BoD 24March2014 .pdf (accessed 7 Oct 2014).

53. Hancock K. The expanding horizon of renewable energy in sub-Saharan Africa:Leading research in the social sciences. Energy Research \& Social Science 2015; 5: 1-8.

54. International Energy Agency. World Energy Outlook 2015 - Electricity Access Database. Paris, 2015.

55. Adair-Rohani H, Zukor K, Bonjour S, et al. Limited electricity access in health facilities of subSaharan Africa: a systematic review of data on electricity access, sources, and reliability. Glob Heal Sci Pract 2013; 1(2): 249-61.

56. Bhatia M, Angelou N, Soni R, et al. Access to Modern Energy Services for Health Facilities in Resource-Constrained Settings: The World Bank and World Health Organization, 2015. 
57. Sokhi RS, Kitwiroon N. Air Pollution in Urban Areas. In: Sokhi RS, ed. World Atlas of Atmospheric Pollution: Anthem Press; 2011: 19-34.

58. Health Effects Institute. Traffic-Related Air Pollution: A Critical Review of the Literature on Emissions, Exposure and Health Effects. 2010; Special Report: 386.

59. Daly HE, Ramea K, Chiodi A, Yeh S, Gargiulo M, Gallachóir BÓ. Incorporating travel behaviour and travel time into TIMES energy system models. APPLIED ENERGY 2014; 135: 429-39.

60. Yim SHL, Stettler MEJ, Barrett SRH. Air quality and public health impacts of UK airports. Part II: Impacts and policy assessment. Atmospheric Environment 2013; 67: 184-92.

61. Yim SHL, Barrett SRH. Public health impacts of combustion emissions in the United Kingdom. Environmental Science \& Technology 2012; 46: 4291-6.

62. Walton BH, Dajnak D, Beevers S, Williams M, Watkiss P, Hunt A. Understanding the Health Impacts of Air Pollution in London. 2015; 2015.

63. Stettler MEJ, Eastham S, Barrett SRH. Air quality and public health impacts of UK airports. Part I: Emissions. Atmospheric Environment 2011; 45: 5415-24.

64. Caiazzo F, Ashok A, Waitz la, Yim SHL, Barrett SRH. Air pollution and early deaths in the United States. Part I: Quantifying the impact of major sectors in 2005. Atmospheric Environment 2013; 79: 198-208.

65. International Energy Agency. Modelling of the transport sector in the Mobility Model (MoMo). 2016. https://www.iea.org/etp/etpmodel/transport/ (accessed 12 Aug 2016).

66. World Cancer Research Fund. Colorectal Cancer Report: Food, nutrition, physical activity, and the prevention of colorectal cancer. London, 2011.

67. Pelster D, Gisore B, Goopy J, et al. Methane and nitrous oxide emissions from cattle excreta on an East African grassland. Journal of Environmental Quality 2016; 45(5): 1531-9.

68. Zhang X, Davidson E, Mauzerall D, Searchinger T, Dumas P. Managing nitrogen for sustainable development. Nature 2015; 528(7580): 51-9.

69. Huang $\mathrm{Y}$, Tang $\mathrm{Y}$. An estimate of greenhouse gas ( $\mathrm{N} 2 \mathrm{O}$ and $\mathrm{CO} 2)$ mitigation potential under various scenarios of nitrogen use efficiency in Chinese croplands. Global Change Biology 2010; 11(16): 2958-70.

70. Grosso S, Parton W, Mosier A, Walsh M, Ojima D, Thornton P. DAYCENT: National-Scale Simulations of Nitrous Oxide Emissions from Cropped Soils in the United States. Journal of Environmental Quality 2006; 35(4): 1451-60.

71. Gilhespy S, Anthony S, Cardenas L, et al. First 20 years of DNDC (DeNitrification DeComposition): Model evolution. Ecological Modelling 2014; 292: 51-62. 
72. Li C, Salas W, Zhang R, Krauter C, Rotz A, Mitloehner F. Manure-DNDC: a biogeochemical process model for quantifying greenhouse gas and ammonia emissions from livestock manure systems. Nutrient Cycling in Agroecosystems 2012; 93(2): 163-200.

73. UK Sustainable Development Unit. Module on Carbon Hotspots. Sustainable Development Strategy for the Health and Care System 2014 - 2020. London; 2014.

74. NHS Sustainable Development Unit. Sustainable Development in Health and Care - Health Check 2016: NHS England \& Public Health England, 2016.

75. Chung J, Meltzer D. Estimate of the Carbon Footprint of the US Healthcare Sector. Journal of the American Medical Association 2009; 302(18): 1970-2.

76. Eckelman M, Sherman J. Environmental Impacts of the US Health Care System and Effects on Public Health. PLOS ONE 2016; 11(6).

77. International Energy Agency. World Energy Investment Outlook. Paris; 2014.

78. Organisation of Economic Co-operation and Development. The Cost of Air Pollution: Health Impacts of Road Transport. Paris, 2014.

79. World Bank Group. State and Trends of Carbon Pricing. Washinton D.C., 2015.

80. Patuelli R, Nijkamp P, Pels E. Environmental tax reform and the double dividend: A metaanalytical performance assessment. Ecological Economics 2005; 55(4): 564-83.

81. Pew Research Center. Climate Change and Financial Instability Seen as Top Global Threats Washington DC: Pew Research Center; 2013.

82. World Bank Group. Public attitudes toward climate change: findings from a multi-country poll. Background note to the world development report 2010. Washington, D.C., 2009.

83. Lorenzoni I, Nicholson-Cole S, Whitmarsh L. Barriers perceived to engaging with climate change among the UK public and their policy implications. Global Environmental Change 2007; 17(34): 445-59.

84. Myers T, Nisbet M, Maibach E, Leiserowitz A. A public health frame arouses hopeful emotions about climate change. Climate Change 2012; 113(3-4): 1105-12.

85. Maibach E, Nisbet M, Baldwin P, Akerlof K, Diao G. Reframing climate change as a public health issue: an exploratory study of public reactions. BMC Public Health 2010; 10(299).

86. Herlihy N, Bar-Hen A, Verner G, et al. Climate Change and Human Health: What are the Research Trends? A scoping review protocol. . BMJ Open (accepted, not published) 2016. 
87. Day T, Höhne N, Gonzales S. Assessing the missed benefits of countries' national contributions: quantifying potential co-benefits. Cologne: New Climate Institute, 2015. 


\section{Appendices}

\section{Appendix 1: Re-considering the health and climate indicators using an adaptation of the DPSEEA Framework:}

Red indicates available data, orange data which can be obtained by data processing or are available only for selected sites and blue markers which require modelling or special data gathering. Related Sustainable Development Goals are indicated where relevant.

\begin{tabular}{|c|c|c|c|c|c|}
\hline \multirow{2}{*}{ Driving Forces } & \multirow{2}{*}{ Pressures } & \multirow{2}{*}{ States/Exposures } & \multirow{2}{*}{ Effects } & \multicolumn{2}{|c|}{ Actions (Responses) } \\
\hline & & & & Specific & General \\
\hline $\begin{array}{l}\text { Dependence on } \\
\text { energy from } \\
\text { combustion of } \\
\text { fossil fuels; other } \\
\text { human activities } \\
\text { leading to } \\
\text { emissions of } \\
\text { climate active } \\
\text { pollutants (CAPs), } \\
\text { including } \\
\text { agriculture and } \\
\text { land use change }\end{array}$ & $\begin{array}{l}\text { Emission of CAPs } \\
\rightarrow \text { altered } \\
\text { concentration in } \\
\text { the atmosphere }\end{array}$ & $\begin{array}{l}\text { Increased radiative } \\
\text { forcing } \rightarrow \text { global } \\
\text { warming, with } \\
\text { regional variations }\end{array}$ & $\begin{array}{l}\text { Impacts on: } \\
\text { - health } \\
\text { - productivity }\end{array}$ & \multicolumn{2}{|c|}{$\begin{array}{l}\text { (1) Measures to adapt to the } \\
\text { effects of climate change } \\
\text { (2) Measures to mitigate climate } \\
\text { change }\end{array}$} \\
\hline \multicolumn{6}{|l|}{ MARKERS } \\
\hline \multirow{3}{*}{ 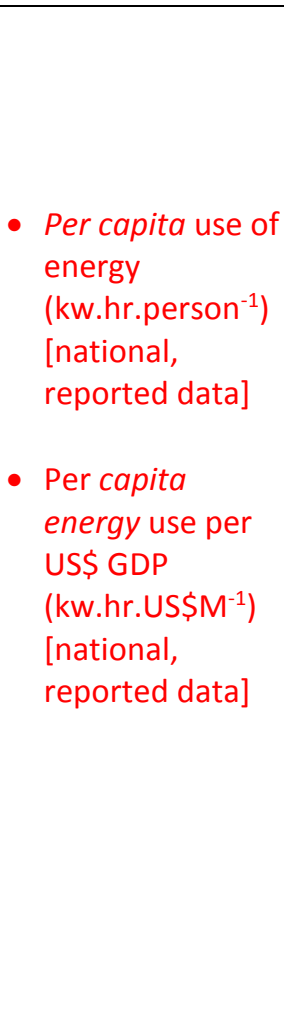 } & \multirow{3}{*}{$\begin{array}{l}\text { - Annual total } \\
\text { and per capita } \\
\text { emissions of } \\
\text { climate active } \\
\text { pollutants } \\
\left.\text { (Gtonne } \mathrm{CO}_{2 .} \mathrm{e}\right) \\
\text { [country, } \\
\text { - } \mathrm{CO}_{2} \\
\mathrm{Concentrations} \\
\text { in atmosphere } \\
\text { (ppmv) } \\
\text { [global, } \\
\text { monitored data } \\
\text { Mauna Loa] }\end{array}$} & $\begin{array}{l}\text { Mean of (warm } \\
\text { season) daily } \\
\text { maximum or mean } \\
\text { temperatures } \\
\text { [city, observed } \\
\text { series] }\end{array}$ & $\begin{array}{l}\text { Heat- (and cold-) } \\
\text { related mortality/ } \\
\text { morbidity } \\
\text { [city, requires epi } \\
\text { modelling] }\end{array}$ & $\begin{array}{l}\text { - Implementati } \\
\text { on of } \\
\text { heatwave } \\
\text { plans } \\
\text { [national] } \\
\text { Building } \\
\text { regulation for } \\
\text { protection } \\
\text { against heat } \\
\text { risks } \\
\text { [national] }\end{array}$ & \multirow{3}{*}{$\begin{array}{l}\text { - Health and } \\
\text { climate } \\
\text { change in the } \\
\text { UNFCCC and } \\
\text { UNGA high- } \\
\text { level } \\
\text { statements } \\
\text { - Academic } \\
\text { publication } \\
\text { and funding } \\
\text { on health and } \\
\text { climate } \\
\text { change } \\
\text { - Integration of } \\
\text { health in } \\
\text { national } \\
\text { adaptation } \\
\text { plans } \\
\text { Direct and } \\
\text { indirect fossil }\end{array}$} \\
\hline & & $\begin{array}{l}\text { Annual mean of } \\
\text { wet bulb globe } \\
\text { temperatures for } \\
\text { working hours } \\
\text { [city, derived } \\
\text { variable] }\end{array}$ & $\begin{array}{l}\text { Reduction in } \\
\text { labour } \\
\text { productivity from } \\
\text { excess heat } \\
\text { [national, model- } \\
\text { based from } \\
\text { WBGT] }\end{array}$ & & \\
\hline & & $\begin{array}{l}\text { Annual total } \\
\text { population and } \\
\text { proportion affected } \\
\text { by flooding }\end{array}$ & $\begin{array}{l}\text { Flood-related } \\
\text { mortality and } \\
\text { morbidity }\end{array}$ & & \\
\hline
\end{tabular}




\begin{tabular}{|c|c|c|c|c|c|}
\hline & & [national] & $\begin{array}{l}\text { (including mental } \\
\text { health) } \\
\text { [national, } \\
\text { immediate } \\
\text { observed deaths } \\
\text { estimable only] }\end{array}$ & & \multirow{4}{*}{$\begin{array}{l}\text { fuel subsidies } \\
\text { [national] } \\
\text { - Adaptation } \\
\text { finance for } \\
\text { health [ } \\
\text { definition] } \\
\text { Change in } \\
\text { annual } \\
\text { investment in } \\
\text { energy } \\
\text { efficiency }\end{array}$} \\
\hline & & $\begin{array}{l}\text { Periods of low } \\
\text { rainfall resulting in } \\
\text { reduced crop yields } \\
\text { [national] }\end{array}$ & $\begin{array}{l}\text { Nutrition-related } \\
\text { growth and } \\
\text { mortality impacts } \\
\text { in children } \\
\text { [national, } \\
\text { requires } \\
\text { modelling] }\end{array}$ & & \\
\hline & & $\begin{array}{l}\text { Warm season mean } \\
\text { of ozone } \\
\text { concentrations? } \\
\text { [city, not specific to } \\
\text { climate change] }\end{array}$ & $\begin{array}{l}\text { Deaths/ } \\
\text { morbidity from } \\
\text { ozone } \\
\text { concentrations } \\
\text { [city, modelled] }\end{array}$ & & \\
\hline & & $\begin{array}{l}\text { Transmissions } \\
\text { potential for } \\
\text { specific vector- } \\
\text { borne diseases } \\
\text { (malaria, dengue) } \\
\text { [sentinel sites, } \\
\text { modelled from } \\
\text { weather data only] }\end{array}$ & $\begin{array}{l}\text { Burdens (cases) } \\
\text { of specific vector- } \\
\text { borne diseases } \\
\text { [national, sentinel } \\
\text { sites] }\end{array}$ & & \\
\hline $\begin{array}{l}\text { Fossil fuel } \\
\text { combustion for } \\
\text { electricity } \\
\text { generation } \\
\text { (Tera-joule per } \\
\text { million population) } \\
\text { [national, reported } \\
\text { data] }\end{array}$ & $\begin{array}{l}\text { - Number (net } \\
\text { capacity in } \\
\text { Gigawatts) of } \\
\text { coal fired } \\
\text { power stations } \\
\text { [national, } \\
\text { reported data] } \\
\text { - Emissions of } \\
\text { CAPs from coal } \\
\text { fired electricity } \\
\text { production } \\
\text { [national] }\end{array}$ & $\begin{array}{l}\text { Ambient } \\
\text { concentration } \\
\text { (annual mean) of } \\
\mathrm{PM}_{2.5} \text { from coal } \\
\text { fired power } \\
\text { generation } \\
\text { [city, requires } \\
\text { modelling or } \\
\text { method of source } \\
\text { apportionment] }\end{array}$ & $\begin{array}{l}\text { Mortality/ } \\
\text { morbidity } \\
\text { attributable to } \\
\text { ambient PM } 2.5 \\
\text { derived from coal } \\
\text { fired generation } \\
\text { [city, model } \\
\text { based] } \\
\\
\underline{\text { SDG 3.9.1 }} \\
\text { mortality } \\
\text { attributable to } \\
\text { household and } \\
\text { ambient AP }\end{array}$ & $\begin{array}{l}\text { Growth in } \\
\text { renewable } \\
\text { energy } \\
\text { resources } \\
\text { [national, } \\
\text { reported } \\
\text { data] } \\
\text { - Renewable } \\
\text { energy patent } \\
\text { generation } \\
\text { and } \\
\text { innovation } \\
\text { [national, } \\
\text { requires } \\
\text { definition] } \\
\text { Note: } \\
\text { SDG 7.1.2 } \\
\text { proportion of } \\
\text { population with }\end{array}$ & $\begin{array}{l}\text { Cost-savings } \\
\text { from the } \\
\text { health co- } \\
\text { benefits } \\
\text { - Coverage and } \\
\text { strength of } \\
\text { carbon pricing } \\
\\
\text { Note } \\
\text { SDG 13.a.1 } \\
\text { Mobilized } \\
\text { US\$/year } \\
\text { towards \$100 } \\
\text { billion } \\
\text { commitment for } \\
\text { CC mitigation }\end{array}$ \\
\hline
\end{tabular}




\begin{tabular}{|c|c|c|c|c|}
\hline & & & $\begin{array}{l}\text { SDG } 11.6 .2 \\
\text { annual mean } \\
\mathrm{PM}_{2.5} \text { in cities }\end{array}$ & $\begin{array}{l}\text { primary reliance } \\
\text { on clean fuels } \\
\text { SDG } 7.2 .1 \\
\text { renewable } \\
\text { energy as share } \\
\text { of final energy } \\
\text { consumption }\end{array}$ \\
\hline $\begin{array}{l}\text { Per capita energy } \\
\text { consumption, } \\
\text { housing sector } \\
\text { [national, reported } \\
\text { data] } \\
\text { Proportion of } \\
\text { housing which is } \\
\text { energy inefficient } \\
\text { [national, requires } \\
\text { definition] }\end{array}$ & $\begin{array}{l}\text { Energy efficiency } \\
\text { of housing stock } \\
\text { (mean energy } \\
\text { requirement to } \\
\text { maintain } \\
\text { standardized } \\
\text { heating and/or } \\
\text { cooling regime, as } \\
\text { well as cooking } \\
\text { and other } \\
\text { household needs) } \\
\text { [national, housing } \\
\text { survey + } \\
\text { modelling] }\end{array}$ & & $\begin{array}{l}\text { Ancillary effects } \\
\text { on deaths/ } \\
\text { morbidity relating } \\
\text { to exposures of } \\
\text { the indoor } \\
\text { environment } \\
\text { [national, model- } \\
\text { based in selected } \\
\text { locations only] }\end{array}$ & $\begin{array}{l}\text { Building } \\
\text { regulation for } \\
\text { energy } \\
\text { efficiency } \\
\text { [national] }\end{array}$ \\
\hline $\begin{array}{l}\text { - Mean per capita } \\
\text { energy use for } \\
\text { transport } \\
\text { (kj.person }{ }^{-1} \text {.year- } \\
{ }^{1} \text { ) } \\
\text { [national, } \\
\text { reported data] } \\
\text { Transport: per } \\
\text { capita distance } \\
\text { travelled by } \\
\text { motorized } \\
\text { transport } \\
\text { [national or city, } \\
\text { survey data] }\end{array}$ & $\begin{array}{l}\text { Transport-related } \\
\text { emissions of } \\
\text { Climate Active } \\
\text { Pollutants and } \\
\text { ambient air } \\
\text { pollutants } \\
\text { [city, emissions } \\
\text { inventories } \\
\text { (where available)] }\end{array}$ & $\begin{array}{l}\text { Ambient air } \mathrm{PM}_{2.5} \\
\text { concentrations } \\
\text { attributable to } \\
\text { transport-related } \\
\text { emissions } \\
\text { [city, requires } \\
\text { modelling or } \\
\text { method of source } \\
\text { apportionment] }\end{array}$ & $\begin{array}{l}\text { Reduction in } \\
\text { deaths/morbidity } \\
\text { from (transport- } \\
\text { related } \\
\text { contribution to) } \\
\text { physical activity } \\
\text { [national or city, } \\
\text { definition of } \\
\text { counterfactual] } \\
\text { Deaths from } \\
\text { transport-related } \\
\text { PM2.5 exposure } \\
\text { [city, model- } \\
\text { based] }\end{array}$ & $\begin{array}{l}\text { - } \begin{array}{l}\text { Deployment } \\
\text { of low- } \\
\text { emission } \\
\text { vehicles }\end{array} \\
\text { - Active } \\
\text { transport } \\
\text { infrastructure } \\
\text { and uptake } \\
\text { [city, } \\
\text { definition] }\end{array}$ \\
\hline $\begin{array}{l}\text { Per capita energy } \\
\text { consumption, food } \\
\text { and agriculture } \\
\text { sector [national, } \\
\text { reported data] }\end{array}$ & & $\begin{array}{l}\text { Per capita } \\
\text { consumption of red } \\
\text { meat \& dairy } \\
\text { products (kilojoules } \\
\text { per person) } \\
\text { [national, survey } \\
\text { based] }\end{array}$ & $\begin{array}{l}\text { Mortality/ } \\
\text { morbidity } \\
\text { attributable to } \\
\text { consumption of } \\
\text { red meat and } \\
\text { dairy products } \\
\text { [national, } \\
\text { modelled and } \\
\text { setting specific] }\end{array}$ & $\begin{array}{l}\frac{\text { Note }}{\text { SDG } 12.3 .1} \\
\text { Global food loss } \\
\text { index }\end{array}$ \\
\hline $\begin{array}{l}\text { [Greenhouse gas } \\
\text { emissions of } \\
\text { healthcare } \\
\text { systems] }\end{array}$ & & & & $\begin{array}{l}\text { Implementation } \\
\text { and health } \\
\text { benefits of the } \\
\text { NDCs [national, } \\
\text { requires special } \\
\text { data gathering } \\
\text { and modelling] }\end{array}$ \\
\hline
\end{tabular}




\section{Appendix 2: Indicators from other monitoring processes relevant to the Lancet Countdown}

The table below maps the Lancet Countdown's indicators with those used for the Sustainable Development Goals, Sendai Framework for Disaster Risk Reduction, ClimateWorks Foundation Carbon Transparency Initiative, and WHO Climate and Health Country Profiles. It is important to note that while the intent of these initiatives is for eventual global coverage, they are still in development and so currently their implementation is limited to some countries. For example, the ClimateWorks Foundation Carbon Transparency Initiative has currently used their indicators for China, the EU, India, Mexico, and the US and WHO have Climate and Health Country Profiles for 40 countries.

\begin{tabular}{|c|c|c|c|c|c|}
\hline $\begin{array}{l}\text { Working } \\
\text { Group }\end{array}$ & $\begin{array}{l}\text { Lancet } \\
\text { Countdown } \\
\text { Indicator } \\
\text { Domains }\end{array}$ & Sustainable Development Goals & $\begin{array}{l}\text { Sendai Framework for Disaster } \\
\text { Risk Reduction }\end{array}$ & $\begin{array}{c}\text { ClimateWorks Foundation } \\
\text { Carbon Transparency } \\
\text { Initiative }\end{array}$ & $\begin{array}{l}\text { WHO Climate and Health } \\
\text { Country Profiles }\end{array}$ \\
\hline \multirow{4}{*}{$\begin{array}{l}\text { Health } \\
\text { Impacts and } \\
\text { Climate } \\
\text { Change }\end{array}$} & $\begin{array}{l}\text { Track populations' } \\
\text { exposure to heat }\end{array}$ & \multirow[t]{4}{*}{$\begin{array}{l}\text { 1.5.1 Number of deaths, missing } \\
\text { persons and persons affected by } \\
\text { disaster per } 100,000 \text { people }\end{array}$} & \multirow{2}{*}{$\begin{array}{l}\text { A-1. Number of deaths and missing } \\
\text { due to hazardous events per } \\
100,000 \text {. } \\
\text { A-2. Number of deaths due to } \\
\text { hazardous events. } \\
\text { A-3. Number of missing due to } \\
\text { hazardous events. } \\
\text { B-1. Number of affected people per } \\
\text { 100,000. }\end{array}$} & & $\begin{array}{l}\text { Warmer and/or fewer cold } \\
\text { days and nights over most land } \\
\text { areas. } \\
\text { Warmer and/or more frequent } \\
\text { hot days and nights over most } \\
\text { land areas. } \\
\text { Heat-related mortality. }\end{array}$ \\
\hline & $\begin{array}{l}\text { Track changes in } \\
\text { labour productivity }\end{array}$ & & & & $\begin{array}{l}\text { Heat stress and work } \\
\text { productivity. }\end{array}$ \\
\hline & $\begin{array}{l}\text { Track populations' } \\
\text { exposure to } \\
\text { heatwaves }\end{array}$ & & $\begin{array}{l}100,000 . \\
\text { B-2. Number of injured or ill people } \\
\text { due to hazardous events. }\end{array}$ & & $\begin{array}{l}\text { Warm spells/heatwaves. } \\
\text { Frequency and/or duration } \\
\text { increases over most land areas. } \\
\text { Heat-related mortality. }\end{array}$ \\
\hline & $\begin{array}{l}\text { Track populations' } \\
\text { exposure to floods }\end{array}$ & & $\begin{array}{l}\text { B-3. Number of people who left their } \\
\text { places of residence due to hazardous } \\
\text { events. } \\
\text { B-3a. Number of evacuated people } \\
\text { due to hazardous events. }\end{array}$ & & $\begin{array}{l}\text { Heavy precipitation events. } \\
\text { Increase in the frequency, } \\
\text { intensity, and/or amount of } \\
\text { heavy precipitation. } \\
\text { Increases in intense tropical } \\
\text { cyclone activity. }\end{array}$ \\
\hline
\end{tabular}




\begin{tabular}{|c|c|c|c|}
\hline & & $\begin{array}{l}\text { B-3b. Number of relocated people } \\
\text { due to hazardous events. } \\
\text { B-4. Number of people whose } \\
\text { houses were damaged due to } \\
\text { hazardous events. } \\
\text { B-5. Number of people whose } \\
\text { houses were destroyed due to }\end{array}$ & $\begin{array}{l}\text { Increased incidence and/or } \\
\text { magnitude of extreme high sea } \\
\text { level. } \\
\text { River flooding. } \\
\text { Exposure to flooding due to sea } \\
\text { level rise. }\end{array}$ \\
\hline $\begin{array}{l}\text { Track populations' } \\
\text { exposure to } \\
\text { droughts }\end{array}$ & & $\begin{array}{l}\text { hazardous events. } \\
\text { B-6. Number of people who received } \\
\text { food relief aid due to hazardous } \\
\text { events. }\end{array}$ & $\begin{array}{l}\text { Increases in intensity and/or } \\
\text { duration of drought. }\end{array}$ \\
\hline $\begin{array}{l}\text { Track the spread of } \\
\text { infectious diseases }\end{array}$ & $\begin{array}{l}\text { 3.3.3 Malaria incidence per } 1,000 \\
\text { population } \\
\text { 3.3.5 Number of people requiring } \\
\text { interventions against neglected } \\
\text { tropical diseases }\end{array}$ & & $\begin{array}{l}\text { Populations at risk of infectious } \\
\text { and vector-borne diseases for } \\
\text { malaria and dengue fever. }\end{array}$ \\
\hline $\begin{array}{l}\text { Track populations' } \\
\text { food security }\end{array}$ & $\begin{array}{l}\text { 2.1.1 Prevalence of } \\
\text { undernourishment } \\
\text { 2.1.2 Prevalence of moderate or } \\
\text { severe food insecurity in the } \\
\text { population, based on the Food } \\
\text { Insecurity Experience Scale (FIES) } \\
\text { 2.2.1 Prevalence of stunting (height } \\
\text { for age <-2 standard deviation from } \\
\text { the median of the World Health } \\
\text { Organization (WHO) Child Growth } \\
\text { Standards) among children under } 5 \\
\text { years of age } \\
\text { 2.2.2 Prevalence of malnutrition } \\
\text { (weight for height }>+2 \text { or <-2 } \\
\text { standard deviation from the median } \\
\text { of the WHO Child Growth } \\
\text { Standards) among children under } 5\end{array}$ & $\begin{array}{l}\text { C-2. Direct agricultural loss due to } \\
\text { hazardous events. }\end{array}$ & \\
\hline
\end{tabular}




\begin{tabular}{|c|c|c|c|c|}
\hline & & $\begin{array}{l}\text { years of age, by type (wasting and } \\
\text { overweight) } \\
\text { 2.4.1 Proportion of agricultural area } \\
\text { under productive and sustainable } \\
\text { agriculture }\end{array}$ & & \\
\hline \multirow{3}{*}{$\begin{array}{l}\text { Health } \\
\text { Resilience } \\
\quad \text { and } \\
\text { Adaptation }\end{array}$} & $\begin{array}{l}\text { Track the } \\
\text { integration of } \\
\text { health in National } \\
\text { Adaptation Plans }\end{array}$ & \multirow{3}{*}{$\begin{array}{l}\text { 3.d.1 International Health } \\
\text { Regulations (IHR) capacity and } \\
\text { health emergency preparedness } \\
\text { 11.b.1 Proportion of local } \\
\text { governments that adopt and } \\
\text { implement local disaster risk } \\
\text { reduction strategies in line with the } \\
\text { Sendai Framework for Disaster Risk } \\
\text { Reduction 2015-2030 } \\
\text { 13.2.1 Number of countries that } \\
\text { have communicated the } \\
\text { establishment or operationalization } \\
\text { of an integrated policy/strategy/plan } \\
\text { which increases their ability to adapt } \\
\text { to the adverse impacts of climate } \\
\text { change, and foster climate resilience } \\
\text { and low greenhouse gas emissions } \\
\text { development in a manner that does } \\
\text { not threaten food production } \\
\text { (including a national adaptation } \\
\text { plan, nationally determined } \\
\text { contribution, national } \\
\text { communication, biennial update } \\
\text { report or other) } \\
\text { 13.3.2 Number of countries that } \\
\text { have communicated the } \\
\text { strengthening of institutional, } \\
\text { systemic and individual capacity- } \\
\text { building to implement adaptation, }\end{array}$} & $\begin{array}{l}\text { E-3. Number of countries that } \\
\text { integrate climate and disaster risk } \\
\text { into development planning. }\end{array}$ & \multirow{3}{*}{$\begin{array}{l}\text { Governance and policy. } \\
\text { Vulnerability, impact and } \\
\text { adaptation (health) } \\
\text { assessments. } \\
\text { Health adaptation strategies } \\
\text { and action plans. } \\
\text { Preparedness, risk } \\
\text { management and integrated } \\
\text { risk monitoring. } \\
\text { Awareness raising and capacity } \\
\text { building. } \\
\text { Financing. }\end{array}$} \\
\hline & $\begin{array}{l}\text { Track climate } \\
\text { services for health }\end{array}$ & & $\begin{array}{l}\text { D-2. Number of health facilities } \\
\text { destroyed or damaged by hazardous } \\
\text { events. }\end{array}$ & \\
\hline & $\begin{array}{l}\text { Track adaptation } \\
\text { finance for health }\end{array}$ & & & \\
\hline
\end{tabular}




\begin{tabular}{|c|c|c|c|c|}
\hline & & $\begin{array}{l}\text { mitigation and technology transfer, } \\
\text { and development actions }\end{array}$ & & \\
\hline \multirow{5}{*}{$\begin{array}{l}\text { Health Co- } \\
\text { Benefits of } \\
\text { Mitigation }\end{array}$} & $\begin{array}{l}\text { Track the phase- } \\
\text { out of coal }\end{array}$ & & $\begin{array}{l}\text { Share amount of coal in total } \\
\text { final energy consumption-that } \\
\text { is, the share of an economy's } \\
\text { energy derived from coal. } \\
\text { Share of electricity from coal } \\
\text { generation. }\end{array}$ & \\
\hline & $\begin{array}{l}\text { Track the growth in } \\
\text { renewable energy } \\
\text { resources }\end{array}$ & $\begin{array}{l}\text { 7.1.2 Proportion of population with } \\
\text { primary reliance on clean fuels and } \\
\text { technology } \\
\text { 7.2.1 Renewable energy share in the } \\
\text { total final energy consumption }\end{array}$ & $\begin{array}{l}\text { Share amount of renewable } \\
\text { energy in total final energy } \\
\text { consumption-that is, an } \\
\text { economy's share of energy } \\
\text { derived from renewable sources. } \\
\text { Share of electricity from } \\
\text { renewable energy generation. }\end{array}$ & \\
\hline & $\begin{array}{l}\text { Track access to } \\
\text { clean energy }\end{array}$ & $\begin{array}{l}\text { 7.1.1 Proportion of population with } \\
\text { access to electricity }\end{array}$ & & \\
\hline & $\begin{array}{l}\text { Track energy access } \\
\text { for health facilities }\end{array}$ & $\begin{array}{l}\text { 3.8.1 Coverage of essential health } \\
\text { services (defined as the average } \\
\text { coverage of essential services based } \\
\text { on tracer interventions that include } \\
\text { reproductive, maternal, newborn } \\
\text { and child health, infectious diseases, } \\
\text { non-communicable diseases and } \\
\text { service capacity and access, among } \\
\text { the general and the most } \\
\text { disadvantaged population) } \\
\text { 3.b.1 Proportion of the population } \\
\text { with access to affordable medicines } \\
\text { and vaccines on a sustainable basis }\end{array}$ & & \\
\hline & $\begin{array}{l}\text { Track ambient air } \\
\text { pollution exposure }\end{array}$ & $\begin{array}{l}\text { 3.9.1 Mortality rate attributed to } \\
\text { household and ambient air pollution } \\
\text { 11.6.2 Annual mean levels of fine } \\
\text { particulate matter (e.g. PM2.5 and }\end{array}$ & & $\begin{array}{l}\text { Current exposures and health } \\
\text { risks due to air pollution, } \\
\text { including outdoor air pollution } \\
\text { exposure, short-lived climate }\end{array}$ \\
\hline
\end{tabular}




\begin{tabular}{|c|c|c|c|}
\hline & $\begin{array}{l}\text { PM10) in cities (population } \\
\text { weighted) }\end{array}$ & & $\begin{array}{l}\text { pollutants, and household air } \\
\text { pollution. }\end{array}$ \\
\hline $\begin{array}{l}\text { Track the } \\
\text { deployment of low } \\
\text { emission vehicles }\end{array}$ & & $\begin{array}{l}\text { Share of new vehicles in a } \\
\text { particular geography that are } \\
\text { electric drive rather than } \\
\text { internal combustion engine } \\
\text { vehicles. } \\
\text { Share of electric drive vehicles } \\
\text { for the light-duty fleet in a } \\
\text { particular year. }\end{array}$ & \\
\hline $\begin{array}{l}\text { Track active } \\
\text { transport } \\
\text { infrastructure and } \\
\text { uptake }\end{array}$ & $\begin{array}{l}\text { 11.2.1 Proportion of population that } \\
\text { has convenient access to public } \\
\text { transport, by sex, age and persons } \\
\text { with disabilities }\end{array}$ & $\begin{array}{l}\text { Total terrestrial passenger } \\
\text { kilometers, meaning the total } \\
\text { number of kilometers that a } \\
\text { population travels, including on } \\
\text { private, public, and passenger } \\
\text { rail. } \\
\text { Number of kilometers travelled } \\
\text { in terrestrial modes - private, } \\
\text { public, and rail-on a per capita } \\
\text { basis. } \\
\text { Total number of kilometers } \\
\text { travelled in private modes- } \\
\text { light-duty vehicles, two } \\
\text { wheelers, and three-wheelers. } \\
\text { Total number of kilometers } \\
\text { travelled in private modes- } \\
\text { light-duty vehicles, two } \\
\text { wheelers, and three-wheelers- } \\
\text { on a per capita basis. } \\
\text { Total number of kilometers } \\
\text { travelled in public modes-bus } \\
\text { and rail. }\end{array}$ & \\
\hline
\end{tabular}




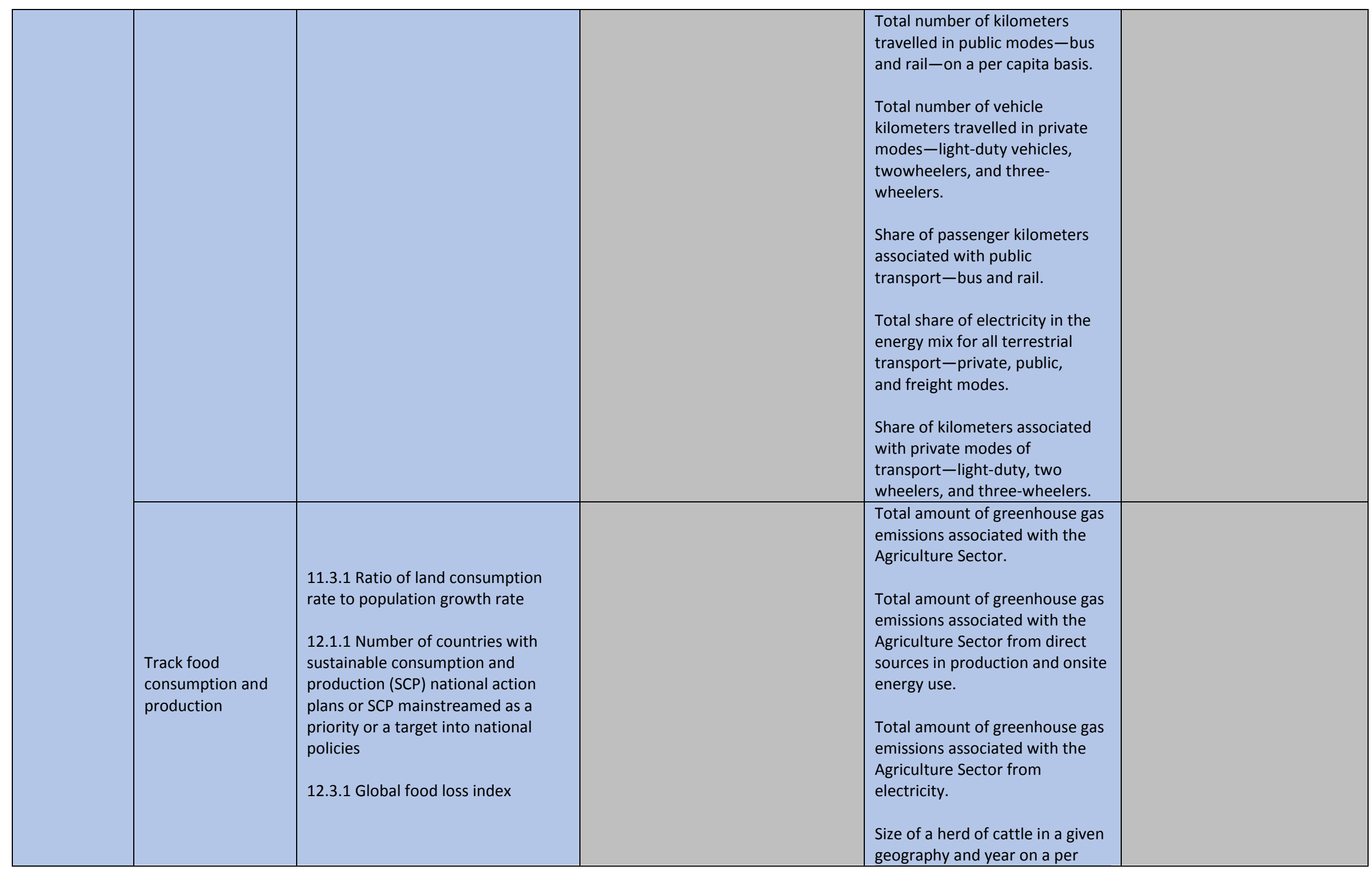




\begin{tabular}{|c|c|c|c|c|}
\hline & & & $\begin{array}{l}\text { capita basis. This metric does not } \\
\text { include dairy cattle. } \\
\text { Share of agricultural emissions } \\
\text { associated with non-dairy cattle. } \\
\text { Share of agricultural emissions } \\
\text { associated with fertilizers. } \\
\text { Greenhouse gas emissions } \\
\text { intensity associated with } \\
\text { agriculture on a per capita basis. }\end{array}$ & \\
\hline & $\begin{array}{l}\text { Track the } \\
\text { greenhouse gas } \\
\text { emissions of } \\
\text { healthcare systems }\end{array}$ & & & $\begin{array}{l}\text { Annual greenhouse gas } \\
\text { emissions by sector (metric } \\
\text { tonnes in } \mathrm{CO} \text {-equivalent) - } \\
\text { although not for healthcare. }\end{array}$ \\
\hline \multirow{6}{*}{$\begin{array}{l}\text { Economics } \\
\text { and Finance }\end{array}$} & $\begin{array}{l}\text { Track change in } \\
\text { annual investment } \\
\text { in renewable } \\
\text { energy }\end{array}$ & \multirow{3}{*}{$\begin{array}{l}\text { 7.2.1 Renewable energy share in the } \\
\text { total final energy consumption } \\
\text { 7.a.1 Mobilized amount of United } \\
\text { States dollars per year starting in } \\
2020 \text { accountable towards the } \$ 100 \\
\text { billion commitment for climate } \\
\text { finance }\end{array}$} & & \\
\hline & $\begin{array}{l}\text { Track change in } \\
\text { annual investment } \\
\text { in energy efficiency }\end{array}$ & & & \\
\hline & $\begin{array}{l}\text { Track low-carbon } \\
\text { technology patent } \\
\text { generation and } \\
\text { innovation }\end{array}$ & & & \\
\hline & $\begin{array}{l}\text { Track the value the } \\
\text { health co-benefits } \\
\text { of climate change } \\
\text { mitigation }\end{array}$ & & & \\
\hline & $\begin{array}{l}\text { Track direct and } \\
\text { indirect fossil fuel } \\
\text { subsidies }\end{array}$ & $\begin{array}{l}\text { 12.c.1 Amount of fossil-fuel } \\
\text { subsidies per unit of GDP } \\
\text { (production and consumption) and } \\
\text { as a proportion of total national } \\
\text { expenditure on fossil fuels }\end{array}$ & & \\
\hline & $\begin{array}{l}\text { Track the coverage } \\
\text { and strength of } \\
\text { carbon pricing }\end{array}$ & & & \\
\hline
\end{tabular}




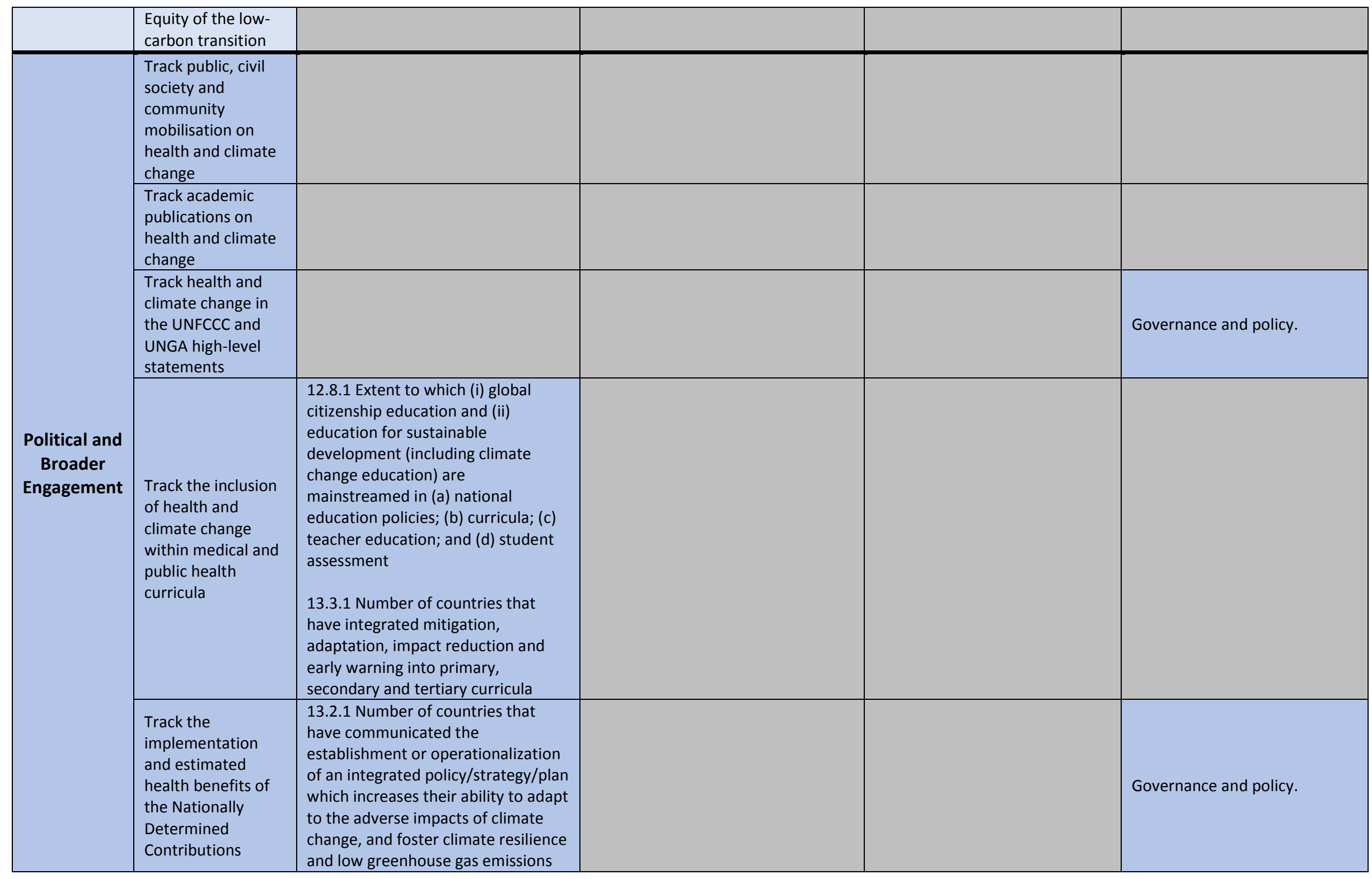




\begin{tabular}{|l|l|l|l|}
\hline & $\begin{array}{l}\text { development in a manner that does } \\
\text { not threaten food production } \\
\text { (including a national adaptation } \\
\text { plan, nationally determined } \\
\text { contribution, national } \\
\text { communication, biennial update } \\
\text { report or other) }\end{array}$ & & \\
\hline
\end{tabular}

